Keywords: Evaporators, Activity Diagrams, Zeolite, 2H

Evaporator, 3H

Evaporator,

Modeling

Retention: Permanent

\title{
THERMODYNAMIC MODELING OF THE SRS EVAPORATORS: PART V. VALIDATION
}

J. M. Pareizs and C. M. Jantzen

Publication Date: April 15, 2003

TTP \#: SR-1-9-WT-31, Subtask D

Westinghouse Savannah River Company 
This document was prepared in conjunction with work accomplished under Contract No. DE-AC09-96SR18500 with the U. S. Department of Energy.

\section{DISCLAIMER}

This report was prepared as an account of work sponsored by an agency of the United States Government. Neither the United States Government nor any agency thereof, nor any of their employees, makes any warranty, express or implied, or assumes any legal liability or responsibility for the accuracy, completeness, or usefulness of any information, apparatus, product or process disclosed, or represents that its use would not infringe privately owned rights. Reference herein to any specific commercial product, process or service by trade name, trademark, manufacturer, or otherwise does not necessarily constitute or imply its endorsement, recommendation, or favoring by the United States Government or any agency thereof. The views and opinions of authors expressed herein do not necessarily state or reflect those of the United States Government or any agency thereof.

This report has been reproduced directly from the best available copy.

Available for sale to the public, in paper, from: U.S. Department of Commerce, National Technical Information Service, 5285 Port Royal Road, Springfield, VA 22161, phone: (800) 553-6847, fax: (703) 605-6900

email: orders@ntis.fedworld.gov

online ordering: http://www.ntis.gov/help/index.asp

Available electronically at http://www.osti.gov/bridge

Available for a processing fee to U.S. Department of Energy and its contractors, in paper, from: U.S. Department of Energy, Office of Scientific and Technical Information, P.O. Box 62, Oak Ridge, TN 37831-0062,

phone: (865)576-8401,

fax: (865)576-5728

email: $\underline{\text { reports@ adonis.osti.gov }}$ 


\section{WSRC-TR-2002-00331, Rev. 0}

\section{EXECUTIVE SUMMARY}

A thermodynamic model has been proposed to predict solids formation in the SRS evaporators from measured feed compositions using a commercially available software package, the Geochemist's Workbench $^{\circledR}$ (GWB). In support of this work, researchers at Pacific Northwest National Laboratory (PNNL) and Oak Ridge National Laboratory (ORNL) have performed experiments to evaluate solids formation under evaporator-like conditions in the laboratory. The purpose of this report is to compare these experimental results to the calculated results from GWB.

Researchers at PNNL conducted experiments to evaluate the thermodynamic boundary between the precipitation of the deleterious sodium aluminosilicate gel $\left(\mathrm{NAS}_{\mathrm{gel}}\right)$ and the field of benign potential precipitation of aluminum hydroxide formation. Several solutions were prepared and held at several temperatures to evaluate solids formation over various periods of time. Observed solids compared well to GWB calculations.

Researchers at ORNL prepared several mixtures of simulated SRS Tank 43 (high aluminum) and DWPF recycle (high silicon) solutions. These solutions were then evaporated, and precipitated solids were examined by XRD. Again, there was good agreement between observations and GWB calculations. No NAS gel was identified, and none was predicted to form.

Researchers at ORNL also prepared several high caustic solutions, additional mixtures of simulated SRS Tank 43 and DWPF solutions, and simulated 3H evaporator feed. Solids deposition on stainless steel coupons with and without evaporation was examined. Because these solids were not rigorously characterized, direct comparison to GWB calculations is not appropriate. However, it should be noted that $\mathrm{NAS}_{\text {gel }}$ was not predicted by GWB to form, and no NAS gel was identified in these experiments.

Overall, the experimental observations validate the GWB calculational results, showing that GWB is an appropriate tool for use in SRS evaporator modeling and control. 


\section{TABLE OF CONTENTS}

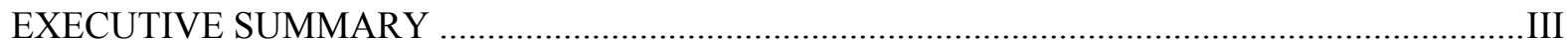

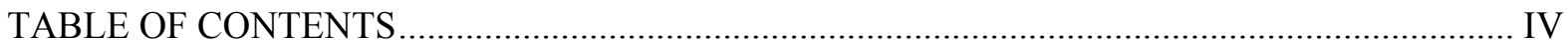

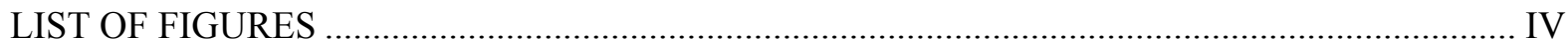

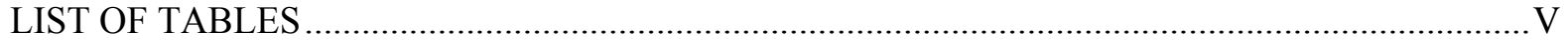

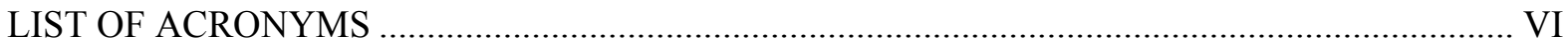

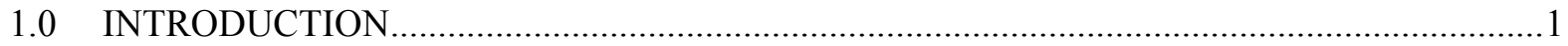

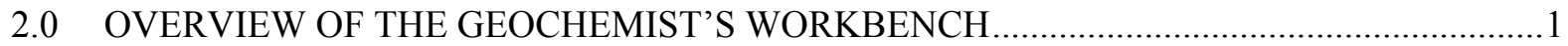

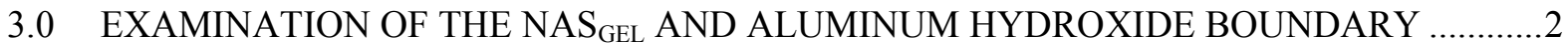

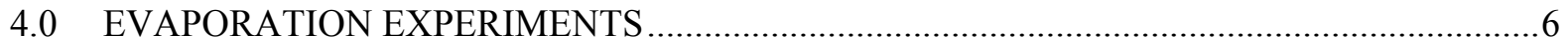

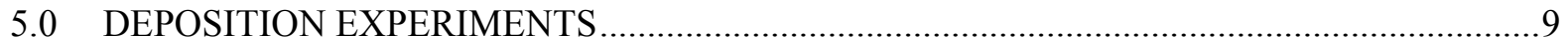

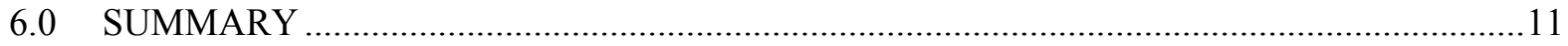

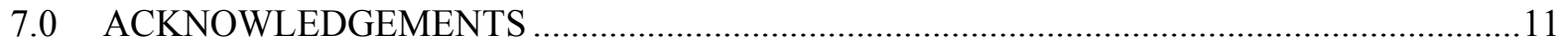

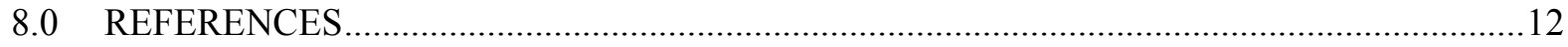

APPENDIX A - MODIFICATION OF GEOCHEMIST'S WORKBENCH ${ }^{\circledR}$

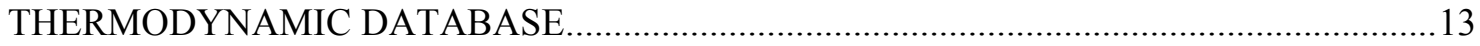

APPENDIX B - SAMPLE REACT AND ACT2 INPUT SCRIPTS …........................................24

APPENDIX C - MATTIGOD EXPERIMENTS AND REACT OUTPUT ........................................25

APPENDIX D - ACTIVITY DIAGRAMS OF MATTIGOD SOLUTIONS …..................................34

\section{LIST OF FIGURES}

Figure 1. Activity Diagrams for the System Al-Si-Na- $\mathrm{NO}_{3}{ }^{-}$Plus $\mathrm{H}_{2} \mathrm{O}$ at $120^{\circ} \mathrm{C}$ for Different Sodium and Nitrate Activities: (a) Mattigod Solutions 1 and 2, (b) Mattigod Solutions 3 and 4, and (c) Mattigod Solutions 5 and 6.

Figure 2. Time-Temperature-Transformation (TTT) diagram of the kinetic data developed by PNNL in support of SRS evaporator modeling

Figure 3. Activity Diagram for the System Al-Si-Na- $\mathrm{NO}_{3}{ }^{-} \mathrm{Plus} \mathrm{H}_{2} \mathrm{O}$ at $120^{\circ} \mathrm{C}$ with Sodium and Nitrate Activities Corresponding to the 75/25 Mixture of Tank 43 and DWPF Recycle at $90 \%$ Evaporation

Figure 4. Activity Diagram for the System Al-Si-Na- $\mathrm{NO}_{3}{ }^{-} \mathrm{Plus} \mathrm{H}_{2} \mathrm{O}$ at $120^{\circ} \mathrm{C}$ with Sodium and Nitrate Activities Corresponding to the 10/90 Mixture of Tank 43 and DWPF Recycle and a $\mathrm{pH}$ of 11

Figure 5. Activity Diagram for the System Al-Si-Na- $\mathrm{NO}_{3}{ }^{-} \mathrm{Plus} \mathrm{H}_{2} \mathrm{O}$ at $120^{\circ} \mathrm{C}$ with Sodium and Nitrate Activities Corresponding to the $42 \%$ Evaporation of Simulated $3 \mathrm{H}$ Evaporator Feed 


\section{LIST OF TABLES}

Table 1. Mattigod Solution Compositions and Calculated $\log \mathrm{Q} / \mathrm{K} \mathrm{NAS}_{\text {gel }}$ at $40^{\circ} \mathrm{C}, 80^{\circ} \mathrm{C}$, $120^{\circ} \mathrm{C}$, and $175^{\circ} \mathrm{C}$

Table 2. Compositions, Calculated $\log \mathrm{Q} / \mathrm{K}$ Values, and Observed Phases for Mixtures of Tank 43 and DWPF Recycle Simulants at 66, 80, and 90\% Evaporation

Table 3. Summary of ORNL Deposition Experiments.

Table A-1. Mineral Decomposition Reactions and Molecular Weights........................................... 13

Table A-2. NAS $_{\text {gel }}$ Equilibrium Compositions (Moles/L solution) ................................................. 14

Table A-3. Zeolite-A Equilibrium Compositions (Moles/L solution) .............................................. 15

Table A-4. Nitrated Sodalite Equilibrium Compositions (Moles/L solution) .................................... 16

Table A-5. Nitrated Cancrinite Compositions (Moles/L solution) ................................................... 17

Table A-6. Calculated Solution Density, Solute Mass, and Composition in Mol $/ \mathrm{kg}$ Water for

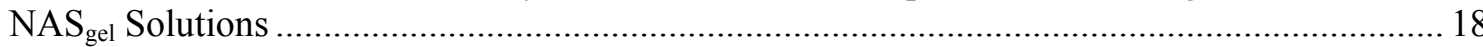

Table A-7. Calculated Solution Density, Solute Mass, and Composition in Mol $/ \mathrm{kg}$ Water for Zeolite-A Solutions.

Table A-8. Calculated Solution Density, Solute Mass, and Composition in Mol $/ \mathrm{kg}$ Water for Nitrated Sodalite Solutions .....

Table A-9. Calculated Solution Density, Solute Mass, and Composition in Mol $/ \mathrm{kg}$ Water for Nitrated Cancrinite Solutions.

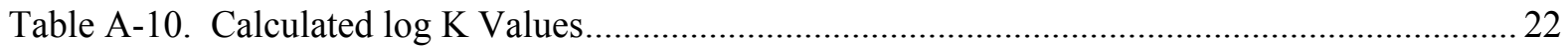

Table A-11. Relationships Between $\log \mathrm{K}$ and Solution Compositions and Temperatures ................ 23

Table A-12. $\log$ K Values for Input into GWB Thermodynamic Database ...................................... 23 
WSRC-TR-2002-00331, Rev. 0

\section{LIST OF ACRONYMS}

DWPF

GWB

$\log \mathrm{Q} / \mathrm{K}$

$\mathrm{NAS}_{\text {gel }}$

ORNL

PNNL

SRTC

XRD
Defense Waste Processing Facility

Geochemist's Workbench $^{\circledR}$

saturation index

sodium aluminosilicate gel

Oak Ridge National Laboratory

Pacific Northwest National Laboratory

Savannah River Technology Center

X-ray diffraction 


\title{
THERMODYNAMIC MODELING OF THE SRS EVAPORATORS: PART V. VALIDATION
}

\author{
J. M. Pareizs and C. M. Jantzen
}

\subsection{INTRODUCTION}

A thermodynamic model has been proposed to predict solids formation in the SRS evaporators from feed compositions (Jantzen et al., 2002a, 2002b, 2003a, 2003b). In support of this work, researchers at Pacific Northwest National Laboratory (PNNL) and Oak Ridge National Laboratory (ORNL) have done experiments to evaluate solids formation under evaporator-like conditions in the laboratory. The purpose of this report is to compare these experimental results to the calculational basis for the thermodynamic evaporator deposition model.

First, a brief overview of the commercially available software used to develop the evaporator model (Geochemist's Workbench ${ }^{\circledR}, \mathrm{GWB}$ ) is presented. Second, the experiments conducted by PNNL to evaluate the thermodynamic boundary between the deleterious sodium aluminosilicate gel $\left(\mathrm{NAS}_{\mathrm{gel}}\right)$ and the field of benign potential precipitation of aluminum hydroxide formation are discussed. The evaporator deposition control model (Jantzen et al., 2003a, 2003b) is based on this boundary. Third, the ORNL evaporation experiments are compared to calculations using GWB. Finally, the solids deposition experiments performed by ORNL with and without volume reduction (evaporation) are discussed.

\subsection{OVERVIEW OF THE GEOCHEMIST'S WORKBENCH}

The Geochemist's Workbench ${ }^{\circledR}$ (GWB) is a set of software tools for manipulating chemical reactions, calculating stability diagrams and the equilibrium states of aqueous solutions, tracing reaction processes, and plotting the results of these calculations (Bethke, 1998). GWB consists of several programs, two of which have been used in evaporator modeling:

- REACT calculates the equilibrium distribution of aqueous species in a fluid and the fluid's saturation state with respect to mineral phases. Evaporation can be modeled by removing water from the system.

- $\quad$ ACT2 is used to calculate and plot activity-activity diagrams (also known as stability diagrams). These diagrams show the stability of minerals and predominance of aqueous species in chemical systems.

Calculations in GWB are based on data in a thermodynamic database*. The database contains decomposition reactions for aqueous species and minerals. The reactions are written in terms of basis species (defined in the database). The base ten $\log$ of the equilibrium constant (log $\mathrm{K}$ ) for each reaction in terms of the basis species at various temperatures is also included in the database. For application of GWB (a software package designed for geochemical modeling) to be used for evaporator modeling, the thermodynamic database had to be modified. Minerals of interest were added to the database, and the equilibrium constants for other minerals were modified to reflect the high ionic

\footnotetext{
* A detailed discussion of the calculational methods employed in GWB can be found in Bethke (1996).
} 
WSRC-TR-2002-00331, Rev. 0

strengths in the evaporators (high relative to geochemical systems), since the $\log \mathrm{K}$ of a given reaction is typically dependant on solution ionic strength. These modifications are documented in Jantzen (2002a).

The equilibrium constants for the additions to the database $\left(\mathrm{NAS}_{\mathrm{gel}}\right.$, Zeolite-A, nitrated sodalite, and nitrated cancrinite ${ }^{\dagger}$ ) were based on limited data in the literature. Therefore, to improve the accuracy and applicability of GWB calculations, researchers at the University of South Australia were contracted to measure the solubilities of these minerals in solutions and at temperatures more relevant to SRS evaporator operation. Descriptions of these experiments and results can be found in AddaiMensah (2002). Calculations of equilibrium constants using the Addai-Mensah results for input into the GWB database is described in Appendix A.

REACT is used to calculate the initial and final (given a change in the system such as an evaporation) equilibrium distribution of aqueous species in a fluid and the fluid's saturation state with respect to mineral phases. Mineral saturation states are determined by a saturation index or $\log Q / K$, where $Q$ is the reaction quotient, and $\mathrm{K}$ is the reaction equilibrium constant. A negative $\log \mathrm{Q} / \mathrm{K}(\mathrm{Q}<\mathrm{K})$ indicates that a solution is predicted to be undersaturated with respect to a given mineral while a positive $\log$ $\mathrm{Q} / \mathrm{K}(\mathrm{Q}>\mathrm{K})$ value indicates that a solution is predicted to be supersaturated with respect to the given mineral.

The REACT module of GWB is configured by defining the bulk composition of a solution and any changes such as temperature or evaporation. Since solution composition is based on one kilogram of water, an evaporation is simulated by removing water. For example, a $20 \%$ evaporation would be simulated by removing 0.2 kilograms of water.

ACT2 is used to calculate and plot activity-activity diagrams. These diagrams are similar to phase diagrams, except instead of mass or mole fraction on the axes, activities are used as the $\mathrm{x}$ and $\mathrm{y}$ variables. They are used to show the equilibrium relationship between minerals and/or aqueous species. Because these diagrams use activities which vary as solution ionic strength changes, they are not easily transposed into molar or mass composition. They are, however, very useful in comparing solutions and graphically illustrating equilibrium between minerals and aqueous species. ACT2 is configured by defining the diagram axes, the species to be shown on the diagram, and any other constraints (e.g. temperature, pressure, bulk solution composition).

Sample input scripts for REACT and ACT2 are presented in Appendix B.

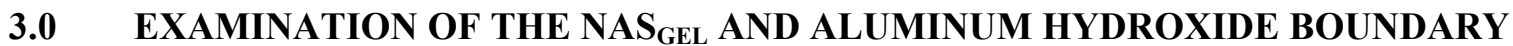

The proposed process control model for the SRS evaporators models the chemical reaction defined by the boundary between $\mathrm{NAS}_{\text {gel }}$ and aluminum hydroxide (Jantzen et al., 2002a, 2003b). This boundary was examined by Mattigod, Hobbs, Parker, and McCready (2002) of PNNL/SRTC. Six solutions were prepared. The first four solutions were designed to be saturated with respect to $\mathrm{NAS}_{\text {gel, }}$, while the last two were designed to be undersaturated with respect to $\mathrm{NAS}_{\text {gel }}$, i.e., saturated with respect to aluminum hydroxide. The solutions were heated to four different temperatures $-40^{\circ} \mathrm{C}, 80^{\circ} \mathrm{C}, 120^{\circ} \mathrm{C}$, and $175^{\circ} \mathrm{C}^{\ddagger}$. The solutions and precipitated solids were sampled over various periods of time to simultaneously study the thermodynamics and kinetics of this controlling reaction. Table 1 gives

\footnotetext{
${ }^{\dagger}$ The chemical composition of $\mathrm{NAS}_{\text {gel }}$ is $\mathrm{Na}_{12} \mathrm{Al}_{12} \mathrm{Si}_{12} \mathrm{O}_{48} \cdot 27 \mathrm{H}_{2} \mathrm{O}$; Zeolite- $\mathrm{A}$ is $\mathrm{Na}_{12} \mathrm{Al}_{12} \mathrm{Si}_{12} \mathrm{O}_{48} \cdot 27 \mathrm{H}_{2} \mathrm{O}$; nitrated sodalite is $\mathrm{Na}_{8} \mathrm{Al}_{6} \mathrm{Si}_{6} \mathrm{O}_{24} \cdot 3.5 \mathrm{H}_{2} \mathrm{O}$; and nitrated cancrinite is $\mathrm{Na}_{8} \mathrm{Al}_{6} \mathrm{Si}_{6} \mathrm{O}_{24} \cdot 2.5 \mathrm{H}_{2} \mathrm{O}$.

${ }^{*}$ Results for $120^{\circ} \mathrm{C}$ and $175^{\circ} \mathrm{C}$ have not been formally published.
} 
each solution composition and the initial calculated $\log \mathrm{Q} / \mathrm{K}$ values at temperatures from $40^{\circ} \mathrm{C}$ to $175^{\circ} \mathrm{C}$.

Table 1. Mattigod Solution Compositions and Calculated $\log Q / \mathrm{KNAS}_{\mathrm{gel}}$ at $40^{\circ} \mathrm{C}, 80^{\circ} \mathrm{C}, 120^{\circ} \mathrm{C}$, and $175^{\circ} \mathrm{C}$

\begin{tabular}{cccccccrrr}
\hline & & & & & \multicolumn{4}{c}{ Calculated $\log \mathrm{Q} / \mathrm{K}\left(\mathrm{NAS}_{\text {gel }}\right)$ from $\mathrm{GWB}$} \\
Solution & $\mathrm{Na}(\mathrm{M})$ & $\mathrm{OH}(\mathrm{M})$ & $\mathrm{NO}_{3}(\mathrm{M})$ & $\mathrm{Si}(\mathrm{M})$ & $\mathrm{Al}(\mathrm{M})$ & $40^{\circ} \mathrm{C}$ & $80^{\circ} \mathrm{C}$ & $120^{\circ} \mathrm{C}$ & $175^{\circ} \mathrm{C}$ \\
\hline 1 & 3.31 & 0.1 & 3 & 0.01 & 0.2 & 8.9 & 9.3 & 12.2 & 14.9 \\
2 & 3.61 & 0.1 & 3 & 0.01 & 0.5 & 10.5 & 14.4 & 17.4 & 19.7 \\
3 & 4.21 & 1.0 & 3 & 0.01 & 0.2 & -3.5 & -4.5 & -2.3 & -1.6 \\
4 & 4.51 & 1.0 & 3 & 0.01 & 0.5 & 1.0 & 0.7 & 2.9 & 3.7 \\
5 & 7.71 & 4.5 & 3 & 0.01 & 0.2 & -11.1 & -14.0 & -12.3 & -12.1 \\
6 & 8.01 & 4.5 & 3 & 0.01 & 0.5 & -5.5 & -8.6 & -6.9 & -6.7 \\
\hline
\end{tabular}

Bulk solution composition (sodium, hydroxide, and nitrate) and measured aluminum and silicon concentrations after each sampling were input into REACT to calculate saturation with respect to $\mathrm{NAS}_{\text {gel }}$, Zeolite-A, nitrated sodalite, and nitrated cancrinite. A complete listing of sampling times, solution analyses, observed phases, and calculated $\log \mathrm{Q} / \mathrm{K}$ values for $\mathrm{NAS}_{\text {gel }}$, Zeolite-A, nitrated sodalite, and nitrated cancrinite are given in Appendix C.

Results are shown graphically on activity diagrams. These diagrams allow one to plot solution composition onto a diagram showing predominant phases and aqueous species. The boundary of interest is defined by the equation (Jantzen et al., 2002a) ${ }^{\S}$

$6 \mathrm{Diaspore}-\mathrm{M}+6 \frac{\mathrm{Al}(\mathrm{OH})_{4}{ }^{-}}{\mathrm{H}^{+}}+12 \mathrm{SiO}_{2}(\mathrm{aq})+12 \mathrm{Na}^{+}+15 \mathrm{H}_{2} \mathrm{O} \longleftrightarrow \mathrm{NAS}_{\mathrm{gel}}$

Figure 1 shows the solutions examined by Mattigod at $120^{\circ} \mathrm{C}$. Diagrams for all solutions at 40,80 , 120 , and $175^{\circ} \mathrm{C}$ are presented in Appendix D.

The experimental observations with respect to $\mathrm{NAS}_{\text {gel }}$ correlate well with GWB calculations and validate the position of the $\mathrm{NAS}_{\text {gel }} /$ aluminum hydroxide boundary. Solutions designed to be undersaturated with respect to $\mathrm{NAS}_{\mathrm{gel}}$ were calculated to be undersaturated. With the exception of Solution $3(\mathrm{OH}=1.0 \mathrm{M}, \mathrm{Al}=0.2 \mathrm{M})$, all other solutions and temperatures were accurately predicted to be saturated with respect to $\mathrm{NAS}_{\mathrm{gel}}$.

It should be noted that Zeolite-A was only observed in significant quantities in Solutions 1 to 4 at $40^{\circ} \mathrm{C}$. This implies that Zeolite-A is not stable in very caustic solutions and at temperatures greater than $40^{\circ} \mathrm{C}$. This is shown graphically on a time-temperature-transformation (TTT) diagram (Figure 2 ). In these diagrams, phases are plotted as functions of time and temperature. The diagrams in Figure 2 were generated from the Mattigod experiments.

For the solutions predicted to be unsaturated with respect to $\mathrm{NAS}_{\mathrm{gel}}$, an amorphous precursor phase was observed, but the composition of the amorphous material was not measured. It is postulated that this phase is the amorphous sodium aluminate phase, $\mathrm{NAS}_{\mathrm{gel}}$.

\footnotetext{
${ }^{\S}$ Diaspore is the predominant phase at temperatures greater than about $120^{\circ}$, while gibbsite is predominant at lower temperatures.
} 
WSRC-TR-2002-00331, Rev. 0

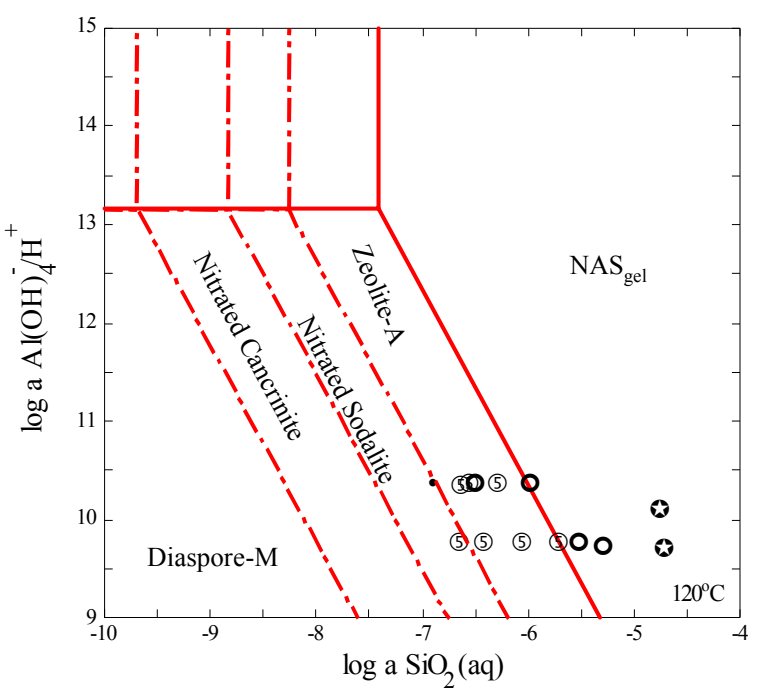

(a)

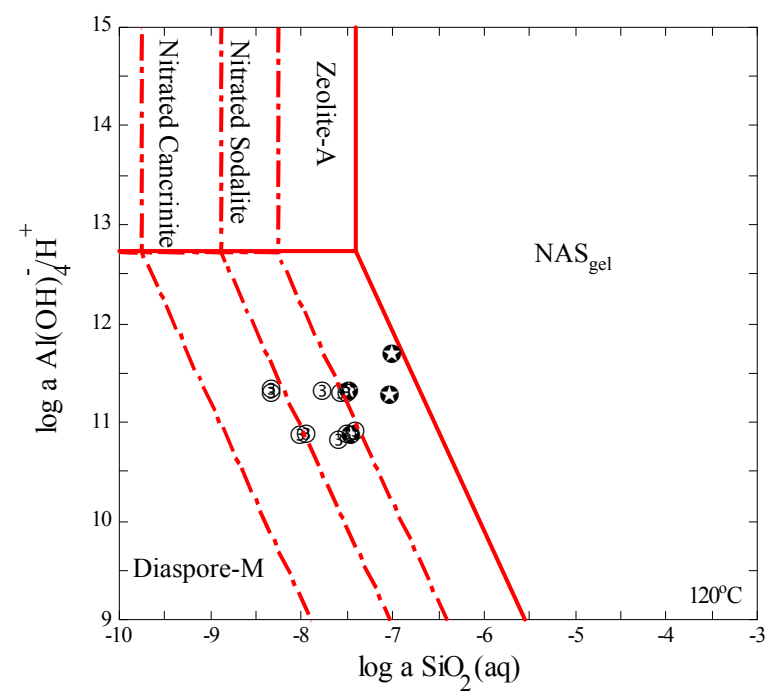

(c)

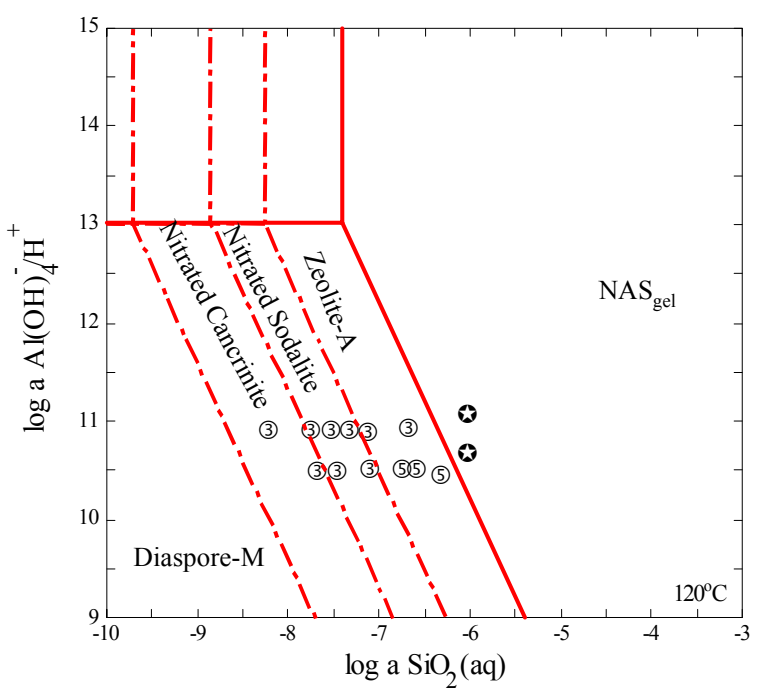

(b)

$\mathrm{X}=$ starting solution star $=$ NAS $_{\text {gel }}$ triangle $=\mathrm{NAS}_{\mathrm{gel}}$ (or amorphous precursor), nitrated sodalite, nitrated cancrinite open diamond $=\mathrm{NAS}_{\mathrm{gel}}$, nitrated sodalite filled diamond $=\mathrm{NAS}_{\mathrm{gel}}$, nitrated sodalite gibbsite

Figure 1. Activity Diagrams for the System Al-Si-Na-NO ${ }_{3}^{-}$Plus $_{2} \mathrm{O}$ at $120^{\circ} \mathrm{C}$ for Different Sodium and Nitrate Activities: (a) Mattigod Solutions 1 and 2, (b) Mattigod Solutions 3 and 4, and (c) Mattigod Solutions 5 and 6 

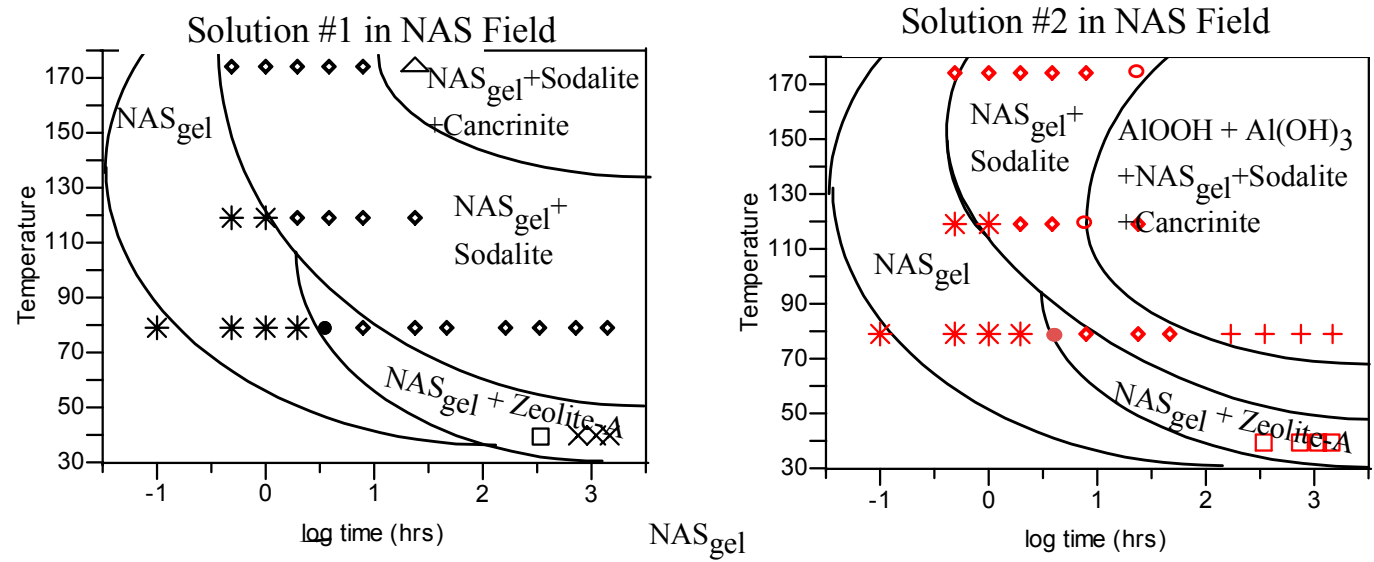

Solution \#3 in NAS Field

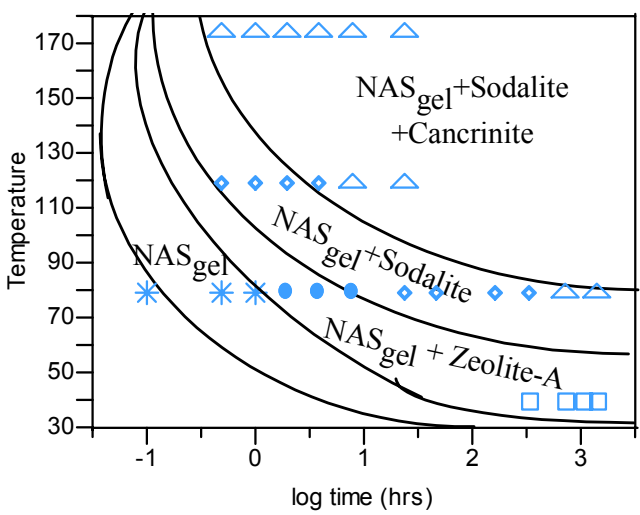

Solution \#4 in NAS Field

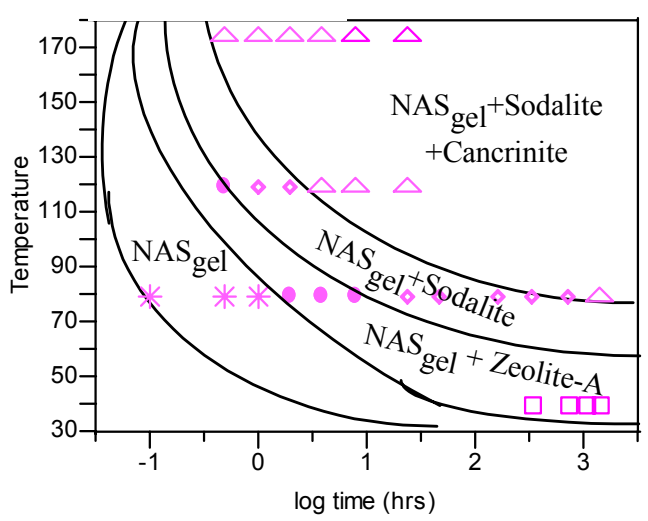

Solution \#5 in Diaspore Field

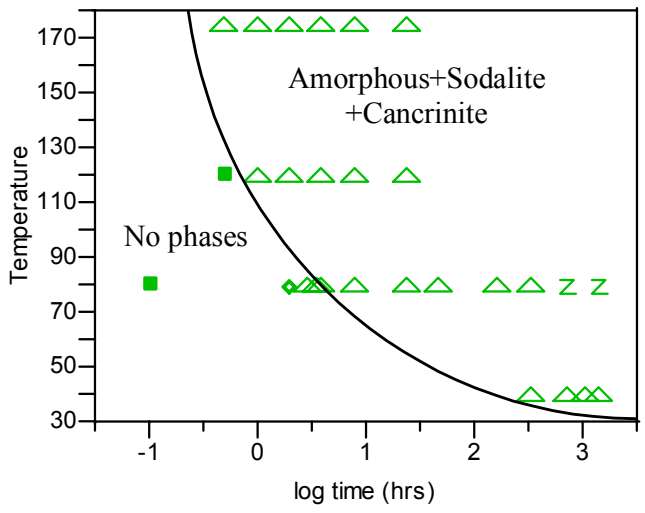

Solution \#6 in Diaspore Field

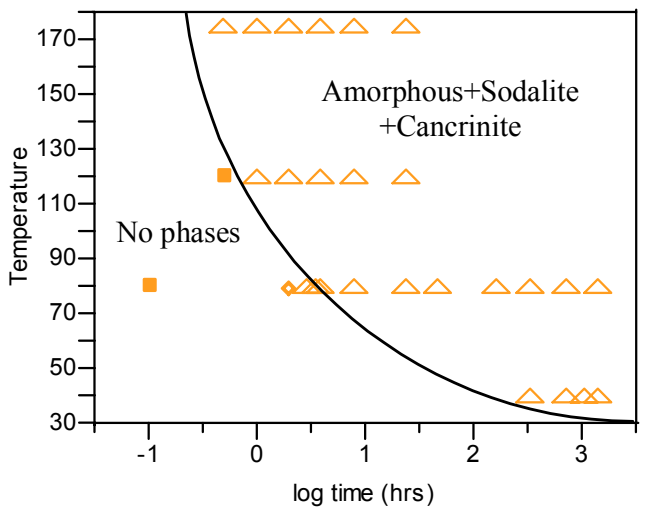

Phase field designations are as follows: $*=\mathrm{NAS}_{\mathrm{gel}} ; \bullet=\mathrm{NAS}_{\text {gel }}+$ Sodalite + Zeolite-A; $\diamond=\mathrm{NAS}_{\text {gel }}+$ Sodalite; $\Delta=\mathrm{NAS}_{\text {gel }}+$ Sodalite + Cancrinite; $\square=\mathrm{NAS}_{\text {gel }}+$ Zeolite-A; $+=\mathrm{Al}(\mathrm{OH})_{3}$, gibbsite; $\mathrm{O}=\mathrm{NAS}$ gel + boehmite + gibbsite

Figure 2. Time-Temperature-Transformation (TTT) diagram of the kinetic data developed by PNNL in support of SRS evaporator modeling

Figure 2 helps to illustrate the relation between thermodynamics and kinetics. For example, the diagrams show that cancrinite, the most stable mineral thermodynamically, but slowest forming 
WSRC-TR-2002-00331, Rev. 0

mineral kinetically, forms more quickly at higher temperatures. The diagrams also show that given the correct time, if a solution is saturated with respect to a particular mineral, that mineral will form.

\subsection{EVAPORATION EXPERIMENTS}

Researchers at ORNL prepared and evaporated various mixtures of Tank 43 and DWPF recycle simulants (Mattus et al., 2002). The purpose of these tests was to evaluate solids formation as a high silicon waste (DWPF recycle) is added to a relatively high aluminum waste (Tank 43). These mixtures were evaporated and evaluated for solids formation. Table 2 summarizes the calculated $\log$ $\mathrm{Q} / \mathrm{K}$ values for the initial mixtures, the observations, and chemistries (calculated) after evaporations of $66 \%, 80 \%$, and $90 \%$.

There is reasonable agreement between calculated mineral saturations $(\log \mathrm{Q} / \mathrm{K})$ and observations. For example, in the 50/50 mixture and 75/25 mixture, the solutions were predicted to be saturated with respect to Zeolite-A after a 90\% evaporation. Compounds identified in Mattus et al. (2002) as unnamed Zeolites with similar chemical compositions to Zeolite-A were indeed observed.

Figure 3 shows the evaporation results graphically on an activity diagram. In this figure, the speciation of $\mathrm{SiO}_{2}(\mathrm{aq})$ is shown. With this representation, the boundary between sodium aluminosilicate minerals and aqueous $\mathrm{Si}$ is shown. $\mathrm{NaH}_{3} \mathrm{SiO}_{4}$ was chosen as the $\mathrm{x}$-axis because it had the highest activity of all the aqueous silicate compounds in the REACT output of these evaporations. This figure does show good agreement between GWB calculations and observations. For the 75/25 and $50 / 50$ mixtures, the figure shows the solutions should be saturated with respect to Zeolite-A, nitrated sodalite, and nitrated cancrinite. Zeolites and nitrated sodalite were indeed observed. Nitrated cancrinite was not observed in any cases. This is due to the length of time of the experiments. GWB calculates saturation based on equilibrium conditions. These solutions were likely not at equilibrium at the time of sampling. Given more time, nitrated cancrinite, the most thermodynamically stable of the minerals of interest, would inevitably have formed.

Other predominant identified phases were High Silica Zeolite $\left(\mathrm{Si}_{16} \mathrm{O}_{32}\right)$, Zeolite Rho $\left(\mathrm{Al}_{12} \mathrm{Si}_{36} \mathrm{O}_{90} \cdot 6 \mathrm{H}_{2} \mathrm{O}\right)$, hydroxy cancrinite, and sodium silicate. The high silica Zeolites and hydroxy cancrinite are not included in the GWB thermodynamic database. Therefore, they cannot be modeled. Sodium silicate is included in the database, and GWB calculations were consistent with observations; GWB predicted saturation with respect to sodium silicate when sodium silicate was observed. 
WSRC-TR-2002-00331, Rev. 0

Table 2. Compositions, Calculated $\log$ Q/K Values, and Observed Phases for Mixtures of Tank 43 and DWPF Recycle Simulants at 66, 80, and $90 \%$ Evaporation

\begin{tabular}{|c|c|c|c|c|c|c|c|c|c|c|c|c|}
\hline $\begin{array}{l}\text { Mix } \\
\text { (Tk 43/ } \\
\text { DWPF } \\
\text { Recycle }\end{array}$ & $\begin{array}{l}\text { Percent } \\
\text { Evaporated }\end{array}$ & $\mathrm{Na}^{+}$ & $\mathrm{OH}^{-}$ & $\begin{array}{c}\text { Solution } \\
\mathrm{NO}_{2}^{-}+ \\
\mathrm{NO}_{3}^{-}\end{array}$ & $\mathrm{CO}_{3}{ }^{2-}$ & $\mathrm{Al}$ & $\mathrm{Si}$ & $\begin{array}{r}\text { Calculate } \\
\log \mathrm{Q} / \mathrm{K} \\
\mathrm{NAS}_{\mathrm{gel}}\end{array}$ & Zeolite-A & $\begin{array}{l}\text { Nitrated } \\
\text { Sodalite }\end{array}$ & $\begin{array}{c}\text { Nitrated } \\
\text { Cancrinite }\end{array}$ & $\begin{array}{c}\text { Observed } \\
\text { Phases }\end{array}$ \\
\hline \multirow[t]{4}{*}{$\overline{10 / 90}$} & 0 & 1.25 & 0.65 & 0.429 & 0.0675 & 0.007 & 0.002 & -32.2 & -21.9 & -10.3 & -5.1 & N/A \\
\hline & 66 & 3.68 & 1.985 & 1.262 & 0.1985 & 0.021 & 0.006 & -25.3 & -15.0 & -5.1 & 0.0 & none \\
\hline & 80 & 6.25 & 3.375 & 2.145 & 0.3375 & 0.035 & 0.010 & -21.3 & -11.0 & -2.4 & 2.8 & none \\
\hline & 90 & 12.50 & 6.750 & 4.290 & 0.6750 & 0.070 & 0.020 & -15.8 & -5.6 & 1.2 & 6.4 & HSZ, SS \\
\hline \multirow[t]{4}{*}{$\overline{50 / 50}$} & 0 & 2.25 & 1.25 & 0.91 & 0.0375 & 0.035 & 0.0018 & -27.1 & -16.8 & -6.7 & -1.5 & $\mathrm{~N} / \mathrm{A}$ \\
\hline & 66 & 6.62 & 3.622 & 2.662 & 0.1103 & 0.103 & 0.005 & -19.3 & -9.0 & -1.2 & 4.0 & none \\
\hline & 80 & 11.25 & 6.157 & 4.525 & 0.1875 & 0.175 & 0.009 & -15.2 & -5.0 & 1.5 & 6.7 & none \\
\hline & 90 & 22.50 & 12.314 & 9.050 & 0.3750 & 0.350 & 0.018 & -9.7 & 0.6 & 5.2 & 10.3 & $\begin{array}{l}\mathrm{HSZ}, \mathrm{Z}, \\
\mathrm{NS}, \mathrm{HC}\end{array}$ \\
\hline \multirow[t]{4}{*}{$75 / 25$} & 0 & 2.88 & 1.63 & 1.20 & 0.0188 & 0.0525 & 0.0016 & -26.5 & -16.2 & -5.9 & -0.8 & N/A \\
\hline & 66 & 8.46 & 4.645 & 3.537 & 0.0551 & 0.154 & 0.005 & -18.5 & -8.2 & -0.4 & 4.7 & none \\
\hline & 80 & 14.38 & 7.897 & 6.013 & 0.0938 & 0.263 & 0.008 & -14.4 & -4.1 & 2.3 & 7.5 & none \\
\hline & 90 & 28.75 & 15.793 & 12.025 & 0.1875 & 0.525 & 0.016 & -8.9 & 1.4 & 5.9 & 11.1 & $\begin{array}{l}\mathrm{HSZ}, \mathrm{Z}, \\
\mathrm{NS}, \mathrm{HC}\end{array}$ \\
\hline
\end{tabular}

${ }^{\dagger} \mathrm{HSZ}=$ high silica Zeolite and Zeolite Rho, SS = Sodium Silicate, Z = Zeolites with $\sim 1: 1: 1 \mathrm{Na:Al:Si}$ ratio (similar to Zeolite-A), NS = nitrated sodalite, $\mathrm{HC}=$ hydroxycancrinite, 


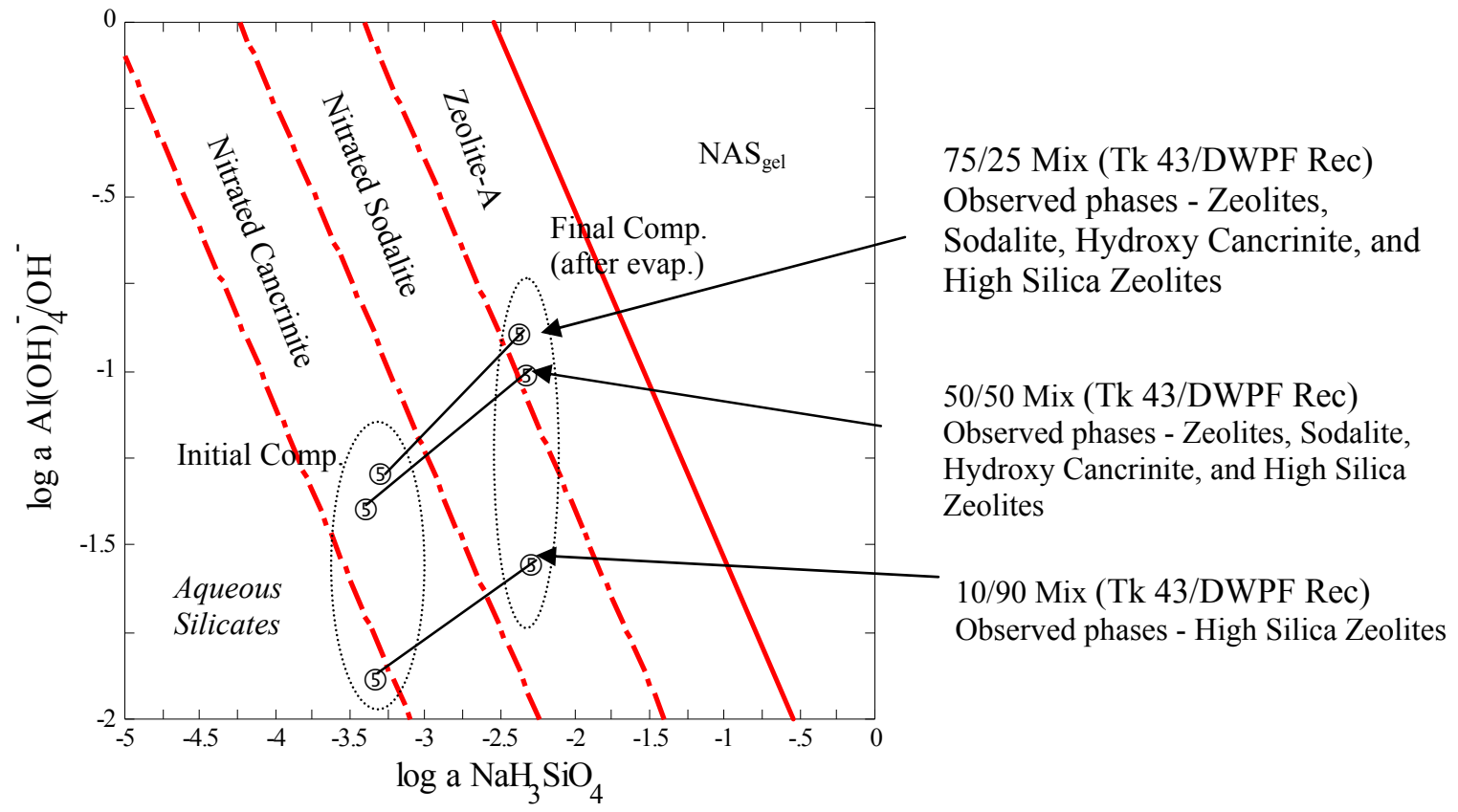

Figure 3. Activity Diagram for the System Al-Si-Na- $\mathrm{NO}_{3}{ }^{-} \mathrm{Plus} \mathrm{H}_{2} \mathrm{O}$ at $120^{\circ} \mathrm{C}$ with Sodium and Nitrate Activities Corresponding to the 75/25 Mixture of Tank 43 and DWPF Recycle at 90\% Evaporation

To illustrate the effect of silicon and aluminum concentrations on the formation of sodium aluminosilicates, Figure 3 was redrawn with an expanded y-axis to show lower aluminum concentration (Figure 4). As can be seen from the figure, as aluminum concentration drops and silicon concentration rises, sodium silicates are predicted to be the predominant solid phases. Based on experimental results, high silica Zeolites will also likely form, but, as stated above, these minerals are not present in the GWB database.

Figure 4 is intended to be illustrative, not exact. The boundary between aqueous silicates and sodium silicate is dependent on $\mathrm{pH}$ - higher $\mathrm{pH}$ shifts this boundary to the left. The impact of silicates other than aluminosilicates on SRS evaporator operations is not fully understood. This impact is being evaluated in future SRTC research*.

It should be noted that while these experiments confirm GWB calculations, they are not directly applicable to the SRS evaporator model as presented by Jantzen et al. (2002a, 2002b, 2003a, 2003b). The evaporator model is based on an average residence time in the evaporator of eight hours and an average evaporation of $40 \%$, while these experiments lasted between eight and sixteen hours with $90 \%$ evaporation.

\footnotetext{
* Research to evaluate the impact of uranium silicates on SRS evaporator operations has been requested by SRS High Level Waste (HLW-TTR-2003-086).
} 


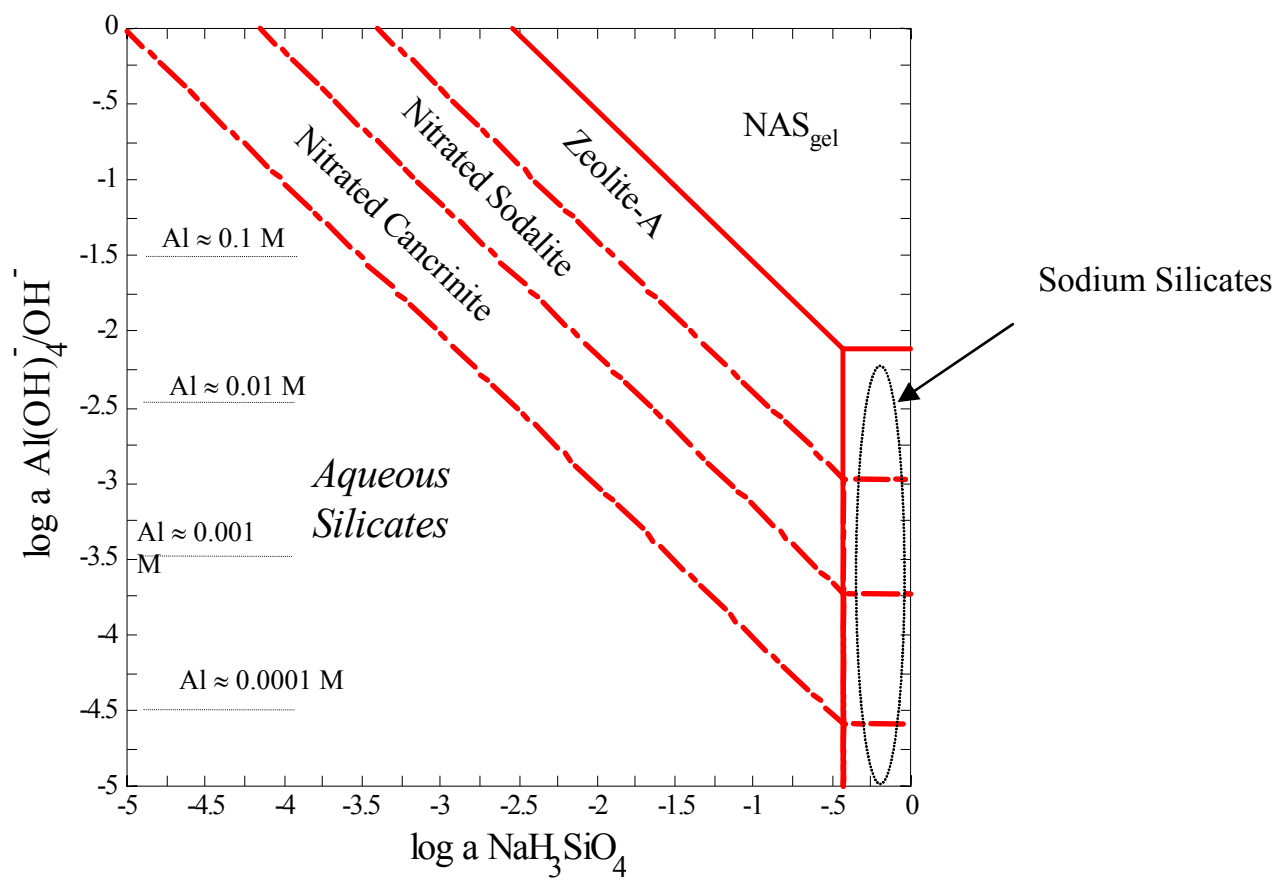

Figure 4. Activity Diagram for the System Al-Si-Na-NO ${ }_{3}^{-}$Plus $\mathrm{H}_{2} \mathrm{O}$ at $120^{\circ} \mathrm{C}$ with Sodium and Nitrate Activities Corresponding to the 10/90 Mixture of Tank 43 and DWPF Recycle and a pH of 11

\subsection{DEPOSITION EXPERIMENTS}

Researchers at ORNL evaluated solids deposition on stainless steel coupons with (1) high sodium concentration solutions, (2) mixtures of Tank 43 and DWPF recycle simulants (SRS 2H Evaporator feed), and (3) simulated SRS 3H Evaporator feed (Hu et al., 2002). With the high sodium solutions, there was no volume reduction - the solutions were heated and allowed to reflux. For the evaporator feeds, the solutions were volume reduced and coupons were examined at various stages of volume reduction.

Table 3 and Figure 5 summarize the results and calculations for the deposition experiments. As in Section 4.0, the figure was drawn with $\mathrm{NaH}_{3} \mathrm{SiO}_{4}$ as the $\mathrm{x}$-axis since it had the highest activity of all the aqueous silicate compounds in the REACT output of these evaporations and solutions.

The observed solids were not rigorously identified, except as sodium aluminosilicate compounds. Without better characterization of these solids, it is difficult to compare observations and calculations. GWB does predict saturation with respect to nitrated cancrinite. With experimental times between four and eight hours and temperatures at approximately $120^{\circ} \mathrm{C}$, the observed particles could be cancrinite (see Solutions 5 and six of the TTT diagrams in Figure 2). 
WSRC-TR-2002-00331, Rev. 0

Table 3. Summary of ORNL Deposition Experiments

\begin{tabular}{|c|c|c|c|c|c|c|c|c|c|c|c|}
\hline \multirow[b]{2}{*}{$\begin{array}{l}\text { No vol. } \\
\text { reduction }\end{array}$} & \multicolumn{6}{|c|}{ Solution Composition (M) } & \multicolumn{4}{|c|}{ Calculated $\log \mathrm{Q} / \mathrm{K}$} & \\
\hline & $\mathrm{Na}^{+}$ & $\mathrm{OH}^{-}$ & $\begin{array}{c}\mathrm{NO}_{2}^{-}+ \\
\mathrm{NO}_{3}^{-}\end{array}$ & $\mathrm{CO}_{3}{ }^{2-}$ & $\mathrm{Al}$ & $\mathrm{Si}$ & $\mathrm{NAS}_{\text {gel }}$ & Zeolite-A & $\begin{array}{l}\text { Nitrated } \\
\text { Sodalite }\end{array}$ & $\begin{array}{c}\text { Nitrated } \\
\text { Cancrinite }\end{array}$ & Observation $^{\dagger}$ \\
\hline & 9.0 & 6.0 & 3.0 & 0 & 0.04 & 0.04 & -16.0 & -5.8 & 0.9 & 6.0 & $\mathrm{~V}$ \\
\hline & 9.0 & 6.0 & 3.0 & 0 & 0.03 & 0.03 & -19.1 & -8.9 & -0.7 & 4.5 & $\mathrm{M}$ \\
\hline & 9.0 & 6.0 & 3.0 & 0 & 0.025 & 0.025 & -21.0 & -10.8 & -1.6 & 3.5 & $\mathrm{M}$ \\
\hline & 9.0 & 6.0 & 3.0 & 0 & 0.02 & 0.02 & -23.4 & -13.2 & -2.8 & 2.3 & None \\
\hline
\end{tabular}

$2 \mathrm{H}$ Feed

(Tk 43/

DWPF

Recycle 26/74 $\begin{array}{llll}66 \% & 4.85 & 2.640 & 1.822\end{array}$ $\begin{array}{llll}80 \% & 8.25 & 4.488 & 3.097\end{array}$ $90 \% 16.50$

$39 / 61$ $90 \% 16.5$

$66 \% \quad 5.81 \quad 3.172 \quad 2.277 \quad 0.1346$

$\begin{array}{lllll}80 \% & 9.88 & 5.393 & 3.871 & 0.2288\end{array}$

$\begin{array}{lllll}90 \% & 19.75 & 10.785 & 7.741 & 0.4575\end{array}$

2.58

$\begin{array}{llll}66 \% & 7.57 & 4.154 & 3.11\end{array}$

$\begin{array}{llll}80 \% & 12.88 & 7.062 & 5.299\end{array}$

$\begin{array}{llll}90 \% & 25.75 & 14.123 & 10.597\end{array}$

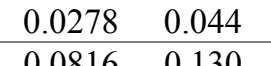

0.0816

0.1388

0.221

0.441

$\begin{array}{lllll}0.018 & 0.002 & -28.8 & -18.5\end{array}$

0.054

0.091

$\begin{array}{lll}0.006 & -21.5 & -11.2\end{array}$

$\begin{array}{lll}0.010 & -17.4 & -7.2\end{array}$

$\begin{array}{lll}0.019 & -12.0 & -1.7\end{array}$

$0.002-27.8-17.5$

$\begin{array}{lll}0.005 & -20.2 & -9.9\end{array}$

$\begin{array}{lll}0.009 & -16.2 & -5.9\end{array}$

$\begin{array}{lll}0.018 & -10.6 & -0.4\end{array}$

0.2775

$0.005-18.8-8.5$

$\begin{array}{lll}0.009 & -14.7 & -4.4\end{array}$

$\begin{array}{rrr}0.009 & -14.7 & -4.4 \\ 0.017 & -9.2 & 1.1\end{array}$

$\begin{array}{rrc}-8.1 & -2.9 & \mathrm{~N} / \mathrm{A} \\ -2.8 & 2.4 & \mathrm{M} \\ 0.0 & 5.1 & \mathrm{M} \\ 3.6 & 8.8 & \mathrm{M} \\ -7.3 & -2.1 & \mathrm{~N} / \mathrm{A} \\ -1.8 & 3.3 & \mathrm{M} \\ 0.9 & 6.1 & \mathrm{M} \\ 4.5 & 9.7 & \mathrm{M} \\ -6.2 & -1.1 & \mathrm{~N} / \mathrm{A} \\ -0.7 & 4.4 & \mathrm{M} \\ 2.0 & 7.2 & \mathrm{M} \\ 5.6 & 10.8 & \mathrm{M}\end{array}$

\begin{tabular}{rrrrrrrrrrrr}
\hline 3H Feed \\
$-14 \%$ & 12.0 & 8.49 & 2.71 & 0 & 0.8 & 0.0021 & -16.1 & -5.8 & 1.0 & 6.1 & N/A \\
$0 \%$ & 13.6 & 9.64 & 3.08 & 0 & 0.9 & 0.0024 & -15.1 & -4.8 & 1.6 & 6.8 & $\mathrm{M}$ \\
$32 \%$ & 20.0 & 14.14 & 4.52 & 0 & 1.3 & 0.0035 & -12.0 & -1.7 & 3.6 & 8.8 & $\mathrm{~V}$ \\
$42 \%$ & 23.5 & 16.64 & 5.31 & 0 & 1.6 & 0.0041 & -10.7 & -0.4 & 4.5 & 9.6 & $\mathrm{M}$ \\
\hline
\end{tabular}

${ }^{\dagger} \mathrm{V}=$ particles visible on stainless steel coupon with the naked eye, $\mathrm{M}=$ particles visible on stainless steel coupon via SEM.

* These experiments began with a solution more dilute than an average $3 \mathrm{H}$ feed. The percent reduction is relative to an average $3 \mathrm{H}$ feed. 
WSRC-TR-2002-00331, Rev. 0

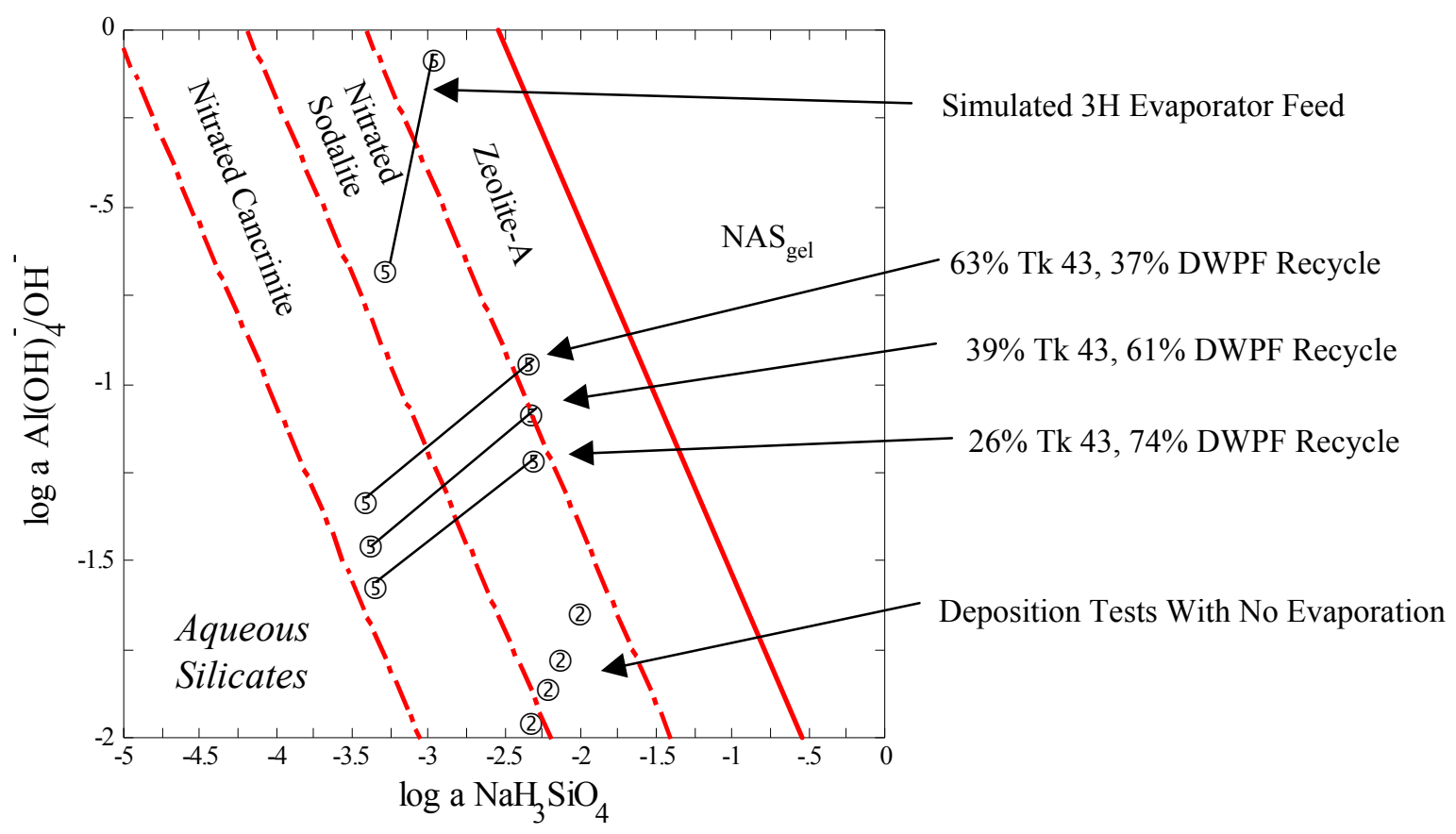

Figure 5. Activity Diagram for the System Al-Si-Na- $\mathrm{NO}_{3}{ }^{-} \mathrm{Plus} \mathrm{H}_{2} \mathrm{O}$ at $120^{\circ} \mathrm{C}$ with Sodium and Nitrate Activities Corresponding to the $42 \%$ Evaporation of Simulated $3 \mathrm{H}$ Evaporator Feed

\subsection{SUMMARY}

- PNNL experiments to evaluate the thermodynamic boundary between the deleterious $\mathrm{NAS}_{\mathrm{gel}}$ and the field of benign aluminum hydroxide formation compared well to GWB calculations. These experiments also validate the boundary between $\mathrm{NAS}_{\text {gel }}$ and aluminum hydroxide.

- There is good agreement between observations from ORNL evaporation experiments using mixtures of simulated Tank 43 and DWPF recycle solutions and GWB calculations. No NAS gel was identified, and none was predicted to form.

- ORNL deposition experiments, although not directly comparable to GWB calculations, showed $\mathrm{NAS}_{\text {gel }}$ was neither observed or predicted.

- Overall, GWB calculational results correlated well with experimental observations, showing that GWB is an appropriate tool for use in SRS evaporator modeling.

\subsection{ACKNOWLEDGEMENTS}

Thomas B. Caldwell is especially thanked for the database that he provided with $>1800$ data points spanning 29 years of operating history in the tank farm that related tank composition to density. This data was used to develop a relationship to relate sodium concentration to solution density for the conversion from molar to molal concentrations.

The authors would like to thank Jonas Addai-Mensah and his research team at the University of South Australia for providing sodium aluminosilicate solubilities in SRS-like solutions. 
WSRC-TR-2002-00331, Rev. 0

The authors would also like to thank Shas Mattigod of PNNL; David Hobbs of SRTC; and Michael $\mathrm{Hu}$, David DePaoli, and Al Mattus for providing the experimental results necessary to validate the GWB calculations.

This work was performed under contract No. DE-AC09-96SR18500 with the Department of Energy and co-funded by the Tank Focus Area under Technical Task Plan \# SR-1-9-WT-31.

\subsection{REFERENCES}

Addai-Mensah, A. J., J. Li, and M. Zbik, 2002, The Chemistry, Crystallization, Physicochemical Properties, and Behavior of Sodium Aluminosilicate Solid Phases: Final Report, WSRC-MS2002-00907, Savannah River Site, Aiken, SC.

Bethke, C. M., 1996, Geochemical Reaction Modeling, Oxford Press, New York.

Bethke, C. M., 1998, The Geochemist's Workbench ${ }^{\circledR}$ Release 3.0, A User's Guide to Rxn, Act2, Tact, React, and Gtplot, University of Illinois Hydrology Program, Urbana, IL .

Hu, M. Z., D. W. DePaoli, and A. J. Mattus, 2002, Results of Deposition Scoping Tests. SMR/SR/EVAP-006, Rev.1, Oak Ridge National Laboratory, Oak Ridge, TN.

Jantzen, C. M., J.E. Laurinat, and K.G. Brown, 2002a, Thermodynamic Modeling of the SRS Evaporators: Part I. The $2 H$ and $2 F$ Systems (U), WSRC-TR-2000-00293, Rev. 1, Savannah River Site, Aiken, SC.

Jantzen,, C. M. J. E. Laurinat, and K. G. Brown, 2002b, Thermodynamic Modeling of the SRS Evaporators: Part II. The 3H System (U), WSRC-TR-2001-00155, Rev. 1, Savannah River Site, Aiken, SC.

Jantzen, C. M., K. G. Brown, T. B. Edwards, and J. M. Pareizs, 2003a, Thermodynamic Modeling of the SRS Evaporators: Part III. Temperature, Evaporation, and Composition Effects on Process Control Strategy, WSRC-TR-2002-00318, Rev. 0, Savannah River Site, Aiken, SC.

Jantzen, C. M., and J. M. Pareizs, 2003b, Thermodynamic Modeling of the SRS Evaporators: Part IV. Incorporation of High Caustic Aluminosilicate Solubility Data (U), WSRC-TR-2002-00319, Rev. 0, Savannah River Site, Aiken, SC.

Mattigod, S. V., D. T. Hobbs, K. E. Parker, and D. E. McCready, 2002, Precipitation of Aluminum Containing Species in Tank Wastes, PNNL-13881, Pacific Northwest Laboratory, Richland, WA.

Mattus, A. J., C. H. Mattus, and R. D. Hunt, 2002, Letter Report on Phase I Evaporation Investigations Utilizing Tank 43 and DWPF Recycle Waste Solution Mixtures. PC/SR/EVAP/LTR/RPT-008, Oak Ridge National Laboratory, Oak Ridge, TN. 


\section{APPENDIX A - MODIFICATION OF GEOCHEMIST'S WORKBENCH ${ }^{\circledR}$ THERMODYNAMIC DATABASE}

The Geochemist's Workbench ${ }^{\circledR}(\mathrm{GWB})$ software package uses equilibrium constants to predict mineral saturation. For the SRS evaporators, minerals of interest are sodium aluminosilicate gel $\left(\mathrm{NAS}_{\mathrm{gel}}\right)$, Zeolite-A, nitrated sodalite, and nitrated cancrinite. Solubility data for these minerals is either not readily available, or the available data is at much lower sodium concentrations than the SRS evaporators (nominally 8.5 molal sodium). Therefore, Jonas Addai-Mensah of the University of South Australia ${ }^{\dagger}$ was contracted to measure solubilities of these minerals at varying solution compositions. These solubilities were then used to calculate equilibrium constants for the GWB thermodynamic database. An outline of the methodology follows.

1. Add the mineral to the database (if it does not already exist). An entry in the database includes the mineral name, molecular weight, molecular formula, decomposition reaction using GWB basis species, and the log of the equilibrium constant at $0,25,60,100,150,200,250$, and $300^{\circ} \mathrm{C}$. At this step all $\log \mathrm{K}$ values are set to zero.

2. Run the react.exe module of GWB with the experimentally determined solution compositions and temperatures. Output will be a $\log \mathrm{Q} / \mathrm{K}$ for each composition and temperature. Since $\log \mathrm{K}$ is set to zero in the database, the calculated $\log \mathrm{Q} / \mathrm{K}$ is equivalent to a calculated $\log \mathrm{K}$.

3. Fit a model of $\log \mathrm{K}$ as a function of composition and temperature.

4. Using the model, calculate $\log \mathrm{K}$ for the composition $8.5 \mathrm{~m} \mathrm{Na}, 3 \mathrm{~m} \mathrm{NO}_{2}{ }^{-}+\mathrm{NO}_{3}{ }^{-}$, and $0.2 \mathrm{~m}$ $\mathrm{Al}(\mathrm{OH})_{4}{ }^{-}$at the following temperatures: $0,25,60,100,150,200,250$, and $300^{\circ} \mathrm{C}$.

5. Enter the $\log \mathrm{K}$ values in the database

In GWB, the basis species that make up each mineral are $\mathrm{H}^{+}, \mathrm{Na}^{+}, \mathrm{Al}^{3+}, \mathrm{SiO}_{2}(\mathrm{aq})$, and $\mathrm{H}_{2} \mathrm{O}^{\ddagger}$. Each mineral formation reaction and molecular weight, as used by GWB, is given in Table A-1. The mineral compositions were determined experimentally ${ }^{\dagger}$.

Table A-1. Mineral Decomposition Reactions and Molecular Weights

\begin{tabular}{lll}
\hline Mineral & Reaction & $\begin{array}{c}\text { Molecular } \\
\text { Weight }\end{array}$ \\
\hline $\mathrm{NAS}_{\text {gel }}$ & $\mathrm{Na}_{12} \mathrm{Al}_{12} \mathrm{Si}_{12} \mathrm{O}_{48} \cdot 27 \mathrm{H}_{2} \mathrm{O}+48 \mathrm{H}^{+} \longleftrightarrow 12 \mathrm{Na}^{+}+12 \mathrm{Al}^{3+}+12 \mathrm{SiO}_{2}(\mathrm{aq})+51 \mathrm{H}_{2} \mathrm{O}$ & 2191 \\
Zeolite-A & $\mathrm{Na}_{12} \mathrm{Al}_{12} \mathrm{Si}_{12} \mathrm{O}_{48} \cdot 27 \mathrm{H}_{2} \mathrm{O}+48 \mathrm{H}^{+} \longleftrightarrow 12 \mathrm{Na}^{+}+12 \mathrm{Al}^{3+}+12 \mathrm{SiO}_{2}(\mathrm{aq})+51 \mathrm{H}_{2} \mathrm{O}$ & 2191 \\
Nitrated Sodalite & $\mathrm{Na}_{8} \mathrm{Al}_{6} \mathrm{Si}_{6} \mathrm{O}_{24} \cdot 3.5 \mathrm{H}_{2} \mathrm{O}+24 \mathrm{H}^{+} \longleftrightarrow 8 \mathrm{Na}^{+}+6 \mathrm{Al}^{3+}+6 \mathrm{SiO}_{2}(\mathrm{aq})+2 \mathrm{NO}_{3}{ }^{-}+15.5 \mathrm{H}_{2} \mathrm{O}$ & 1085 \\
$\begin{array}{l}\text { Nitrated } \\
\text { Cancrinite }\end{array}$ & $\mathrm{Na}_{8} \mathrm{Al}_{6} \mathrm{Si}_{6} \mathrm{O}_{24} \cdot 2.5 \mathrm{H}_{2} \mathrm{O}+24 \mathrm{H}^{+} \longleftrightarrow 8 \mathrm{Na}^{+}+6 \mathrm{Al}^{3+}+6 \mathrm{SiO}_{2}(\mathrm{aq})+2 \mathrm{NO}_{3}{ }^{-}+14.5 \mathrm{H}_{2} \mathrm{O}$ & 1067 \\
\hline
\end{tabular}

${ }^{\dagger}$ Addai-Mensah, A. J., J. Li, and M. Zbik, The Chemistry, Crystallization, Physicochemical Properties, and Behavior of Sodium Aluminosilicate Solid Phases, SRT-LWP-2002-00060, Savannah River Site, Aiken, SC.

* The actual species that are involved in the reaction (e.g., $\mathrm{Al}(\mathrm{OH})_{4}{ }^{-}$) are swapped for basis species when running the REACT.exe application. 
WSRC-TR-2002-00331, Rev. 0

To calculate solubility concentrations of silicon and aluminum, each mineral was dissolved in a variety of solutions at several temperatures. After equilibrium was reached, the silicon and aluminum concentrations were measured. For input into REACT, the solution composition at equilibrium was calculated. Based on measured silicon concentration, sodium, nitrate, and nitrite concentrations were adjusted using the stoichiometry in Table A-1. For example, one mole of sodium is formed per mole of silicon as the mineral Zeolite-A dissolves. Also, aluminum is shown in the form $\mathrm{Al}(\mathrm{OH})_{4}{ }_{4}$, silicon in the form $\mathrm{H}_{2} \mathrm{SiO}_{4}{ }^{2-}$, and hydroxide is calculated from a charge balance. Table A-2 through Table A5 list the equilibrium solution compositions for the Addai-Mensah solubility experiments.

Table A-2. NAS $_{\text {gel }}$ Equilibrium Compositions (Moles/L solution)

\begin{tabular}{lcccccc}
\hline Solution ID & $\mathrm{Na}^{+}$ & $\mathrm{OH}^{-}$ & $\mathrm{NO}_{3}{ }^{-}$ & $\mathrm{NO}_{2}^{-}$ & $\mathrm{H}_{2} \mathrm{SiO}_{4}{ }^{-2}$ & $\mathrm{Al}(\mathrm{OH})_{4}{ }^{-}$ \\
\hline $\mathrm{T}=30^{\circ} \mathrm{C}$ & & & & & & \\
NAS-1 & 3.0702 & 2.8507 & 0 & 0 & 0.0702 & 0.0791 \\
NAS-2 & 6.1013 & 5.7998 & 0 & 0 & 0.1013 & 0.0989 \\
NAS-3 & 6.0861 & 3.8348 & 1 & 1 & 0.0861 & 0.0791 \\
NAS-4 & 6.0558 & 3.7501 & 1 & 1 & 0.0558 & 0.1941 \\
NAS-5 & 6.0398 & 3.4899 & 1 & 1 & 0.0398 & 0.4703 \\
NAS-6 & 12.1088 & 7.7821 & 2 & 2 & 0.1088 & 0.1091 \\
NAS-7 & 12.0852 & 7.6947 & 2 & 2 & 0.0852 & 0.2201 \\
NAS-8 & 12.0564 & 7.4332 & 2 & 2 & 0.0564 & 0.5104 \\
T $=65^{\circ} \mathrm{C}$ & & & & & & \\
NAS-9 & 3.0881 & 2.807 & 0 & 0 & 0.0881 & 0.1049 \\
NAS-10 & 6.2074 & 5.5865 & 0 & 0 & 0.2074 & 0.2061 \\
NAS-11 & 6.1163 & 3.7587 & 1 & 1 & 0.1163 & 0.125 \\
NAS-12 & 6.0705 & 3.7243 & 1 & 1 & 0.0705 & 0.2052 \\
NAS-13 & 6.0454 & 3.4463 & 1 & 1 & 0.0454 & 0.5083 \\
NAS-14 & 12.2578 & 7.458 & 2 & 2 & 0.2578 & 0.2842 \\
NAS-15 & 12.1937 & 7.4555 & 2 & 2 & 0.1937 & 0.3508 \\
NAS-16 & 12.1447 & 7.2757 & 2 & 2 & 0.1447 & 0.5796 \\
T $=130^{\circ} \mathrm{C}$ & & & & & & \\
NAS-17 & 3.1119 & 2.7749 & 0 & 0 & 0.1119 & 0.1132 \\
NAS-18 & 6.2934 & 5.4114 & 0 & 0 & 0.2934 & 0.2952 \\
NAS-19 & 6.1565 & 3.6846 & 1 & 1 & 0.1565 & 0.1589 \\
NAS-20 & 6.0892 & 3.6826 & 1 & 1 & 0.0892 & 0.2282 \\
NAS-21 & 6.0576 & 3.4316 & 1 & 1 & 0.0576 & 0.5108 \\
\hline
\end{tabular}


WSRC-TR-2002-00331, Rev. 0

Table A-3. Zeolite-A Equilibrium Compositions (Moles/L solution)

\begin{tabular}{|c|c|c|c|c|c|c|}
\hline Solution ID & $\mathrm{Na}^{+}$ & $\mathrm{OH}^{-}$ & $\mathrm{NO}_{3}^{-}$ & $\mathrm{NO}_{2}^{-}$ & $\mathrm{H}_{2} \mathrm{SiO}_{4}^{2-}$ & $\mathrm{Al}(\mathrm{OH})_{4}$ \\
\hline $\mathrm{T}=30^{\circ} \mathrm{C}$ & & & & & & \\
\hline ZEO-1 & 3.0118 & 2.9681 & 0 & 0 & 0.0118 & 0.0201 \\
\hline ZEO-2 & 6.0314 & 5.9187 & 0 & 0 & 0.0314 & 0.0499 \\
\hline ZEO-3 & 6.0151 & 3.9535 & 1 & 1 & 0.0151 & 0.0314 \\
\hline ZEO-4 & 6.0059 & 3.8456 & 1 & 1 & 0.0059 & 0.1485 \\
\hline ZEO-5 & 6.0042 & 3.5558 & 1 & 1 & 0.0042 & 0.44 \\
\hline ZEO-6 & 12.039 & 7.9002 & 2 & 2 & 0.039 & 0.0608 \\
\hline ZEO-7 & 12.0221 & 7.8122 & 2 & 2 & 0.0221 & 0.1657 \\
\hline $\begin{array}{l}\text { ZEO- } 8 \\
\qquad \mathrm{~T}=65^{\circ} \mathrm{C}\end{array}$ & 12.0172 & 7.5225 & 2 & 2 & 0.0172 & 0.4603 \\
\hline ZEO-9 & 3.0199 & 2.9532 & 0 & 0 & 0.0199 & 0.0269 \\
\hline ZEO-10 & 6.044 & 5.8824 & 0 & 0 & 0.044 & 0.0736 \\
\hline ZEO-11 & 6.0201 & 3.9516 & 1 & 1 & 0.0201 & 0.0283 \\
\hline ZEO-12 & 6.008 & 3.8154 & 1 & 1 & 0.008 & 0.1766 \\
\hline ZEO-13 & 6.0053 & 3.5386 & 1 & 1 & 0.0053 & 0.4561 \\
\hline ZEO-14 & 12.0681 & 7.8358 & 2 & 2 & 0.0681 & 0.0961 \\
\hline ZEO-15 & 12.0363 & 7.6828 & 2 & 2 & 0.0363 & 0.2809 \\
\hline $\begin{array}{l}\text { ZEO- } 16 \\
\qquad \mathrm{~T}=130^{\circ} \mathrm{C}\end{array}$ & 12.0249 & 7.4914 & 2 & 2 & 0.0249 & 0.4837 \\
\hline ZEO-17 & 3.0309 & 2.9349 & 0 & 0 & 0.0309 & 0.0342 \\
\hline ZEO-18 & 6.0618 & 5.8667 & 0 & 0 & 0.0618 & 0.0715 \\
\hline ZEO-19 & 6.0306 & 3.9343 & 1 & 1 & 0.0306 & 0.0351 \\
\hline ZEO-20 & 6.0105 & 3.8247 & 1 & 1 & 0.0105 & 0.1648 \\
\hline ZEO-21 & 6.0074 & 3.5282 & 1 & 1 & 0.0074 & 0.4644 \\
\hline ZEO-22 & 12.1007 & 7.7991 & 2 & 2 & 0.1007 & 0.1002 \\
\hline ZEO-23 & 12.054 & 7.7406 & 2 & 2 & 0.054 & 0.2054 \\
\hline ZEO-24 & 12.0354 & 7.4766 & 2 & 2 & 0.0354 & 0.488 \\
\hline
\end{tabular}


WSRC-TR-2002-00331, Rev. 0

Table A-4. Nitrated Sodalite Equilibrium Compositions (Moles/L solution)

\begin{tabular}{lcccccc}
\hline & $\mathrm{Na}^{+}$ & $\mathrm{OH}^{-}$ & $\mathrm{NO}_{3}{ }^{-}$ & $\mathrm{NO}_{2}{ }^{-}$ & $\mathrm{H}_{2} \mathrm{SiO}_{4}{ }^{2-}$ & $\mathrm{Al}(\mathrm{OH})_{4}{ }^{-}$ \\
\hline $\mathrm{T}=30^{\circ} \mathrm{C}$ & & & & & & \\
SOD-1 & 3.0104 & 2.9817 & 0.0013 & 0.0013 & 0.0078 & 0.0105 \\
Sod-2 & 6.0236 & 5.9624 & 0.0029 & 0.0029 & 0.0177 & 0.0199 \\
SOD-3 & 6.0077 & 3.9880 & 1.0010 & 1.0010 & 0.0058 & 0.0062 \\
SOD-4 & 6.0032 & 3.8448 & 1.0004 & 1.0004 & 0.0024 & 0.1528 \\
SOD-5 & 6.0011 & 3.5596 & 1.0001 & 1.0001 & 0.00081 & 0.4396 \\
SOD-6 & 12.0105 & 7.9725 & 2.0013 & 2.0013 & 0.0079 & 0.0196 \\
SOD-7 & 12.0043 & 7.8463 & 2.0005 & 2.0005 & 0.0032 & 0.1505 \\
SOD-8 & 12.0028 & 7.5477 & 2.0004 & 2.0004 & 0.0021 & 0.4502 \\
$\mathrm{~T}=65^{\circ} \mathrm{C}$ & & & & & & \\
SOD-9 & 3.0191 & 2.9705 & 0.0024 & 0.0024 & 0.0143 & 0.0152 \\
SOD-10 & 6.0432 & 5.9277 & 0.0054 & 0.0054 & 0.0324 & 0.0399 \\
SOD-11 & 6.0167 & 3.9703 & 1.0021 & 1.0021 & 0.0125 & 0.0172 \\
SOD-12 & 6.0036 & 3.8384 & 1.0005 & 1.0005 & 0.0027 & 0.1589 \\
SOD-13 & 6.0021 & 3.5517 & 1.0003 & 1.0003 & 0.0016 & 0.4467 \\
SOD-14 & 12.0241 & 7.9588 & 2.0030 & 2.0030 & 0.0181 & 0.0231 \\
SOD-15 & 12.0071 & 7.8390 & 2.0009 & 2.0009 & 0.0053 & 0.1557 \\
SOD-16 & 12.0043 & 7.5377 & 2.0005 & 2.0005 & 0.0032 & 0.4591 \\
$\mathrm{~T}=130^{\circ} \mathrm{C}$ & & & & & & \\
SOD-17 & 3.0301 & 2.9478 & 0.0038 & 0.0038 & 0.0226 & 0.0296 \\
SOD-18 & 6.0579 & 5.9081 & 0.0072 & 0.0072 & 0.0434 & 0.0485 \\
SOD-19 & 6.0233 & 3.9616 & 1.0029 & 1.0029 & 0.0175 & 0.0209 \\
SOD-20 & 6.0049 & 3.8403 & 1.0006 & 1.0006 & 0.0037 & 0.156 \\
SOD-21 & 6.0033 & 3.5465 & 1.0004 & 1.0004 & 0.0025 & 0.451 \\
SOD-22 & 12.0397 & 7.9397 & 2.0050 & 2.0050 & 0.0298 & 0.0305 \\
SOD-23 & 12.0125 & 7.8307 & 2.0016 & 2.0016 & 0.0094 & 0.1599 \\
SOD-24 & 12.0083 & 7.5334 & 2.0010 & 2.0010 & 0.0062 & 0.4604 \\
\hline
\end{tabular}


WSRC-TR-2002-00331, Rev. 0

Table A-5. Nitrated Cancrinite Compositions (Moles/L solution)

\begin{tabular}{lcccccc}
\hline Solution ID & $\mathrm{Na}^{+}$ & $\mathrm{OH}^{-}$ & $\mathrm{NO}_{3}^{-}$ & $\mathrm{NO}_{2}{ }^{-}$ & $\mathrm{H}_{2} \mathrm{SiO}_{4}{ }^{2-}$ & $\mathrm{Al}(\mathrm{OH})_{4}{ }^{-}$ \\
\hline $\mathrm{T}=30^{\circ} \mathrm{C}$ & & & & & & \\
$\mathrm{CAN}-1$ & 3.0061 & 2.9875 & 0.0008 & 0.0008 & 0.0046 & 0.0079 \\
$\mathrm{CAN}-2$ & 6.0121 & 5.9792 & 0.0015 & 0.0015 & 0.0091 & 0.0117 \\
$\mathrm{CAN}-3$ & 6.0025 & 3.9948 & 1.0003 & 1.0003 & 0.0019 & 0.0033 \\
$\mathrm{CAN}-4$ & 6.0004 & 3.8532 & 1.0001 & 1.0001 & 0.0003 & 0.1465 \\
$\mathrm{CAN}-5$ & 6.0003 & 3.5596 & 1.0000 & 1.0000 & 0.0002 & 0.4402 \\
$\mathrm{CAN}-6$ & 12.0027 & 7.9903 & 2.0003 & 2.0003 & 0.0020 & 0.0077 \\
$\mathrm{CAN}-7$ & 12.0005 & 7.8497 & 2.0001 & 2.0001 & 0.0004 & 0.1499 \\
$\mathrm{CAN}-8$ & 12.0004 & 7.5538 & 2.0000 & 2.0000 & 0.0003 & 0.4459 \\
$\mathrm{~T}=65^{\circ} \mathrm{C}$ & & & & & & \\
$\mathrm{CAN}-9$ & 3.0095 & 2.9828 & 0.0012 & 0.0012 & 0.0071 & 0.0101 \\
$\mathrm{CAN}-10$ & 6.0187 & 5.9712 & 0.0023 & 0.0023 & 0.0140 & 0.0148 \\
$\mathrm{CAN}-11$ & 6.0033 & 3.9918 & 1.0004 & 1.0004 & 0.0025 & 0.0057 \\
$\mathrm{CAN}-12$ & 6.0007 & 3.8496 & 1.0001 & 1.0001 & 0.0005 & 0.1499 \\
$\mathrm{CAN}-13$ & 6.0004 & 3.5571 & 1.0001 & 1.0001 & 0.0003 & 0.4426 \\
$\mathrm{CAN}-14$ & 12.0043 & 7.9855 & 2.0005 & 2.0005 & 0.0032 & 0.0113 \\
$\mathrm{CAN}-15$ & 12.0008 & 7.8507 & 2.0001 & 2.0001 & 0.0006 & 0.1487 \\
$\mathrm{CAN}-16$ & 12.0005 & 7.5474 & 2.0001 & 2.0001 & 0.0004 & 0.4522 \\
$\mathrm{~T}=130^{\circ} \mathrm{C}$ & & & & & \\
$\mathrm{CAN}-17$ & 3.0137 & 2.9762 & 0.0017 & 0.0017 & 0.0103 & 0.0135 \\
$\mathrm{CAN}-18$ & 6.0249 & 5.9591 & 0.0031 & 0.0031 & 0.0187 & 0.0222 \\
$\mathrm{CAN}-19$ & 6.0068 & 3.9868 & 1.0009 & 1.0009 & 0.0051 & 0.0081 \\
$\mathrm{CAN}-20$ & 6.0009 & 3.8396 & 1.0001 & 1.0001 & 0.0007 & 0.1597 \\
$\mathrm{CAN}-21$ & 6.0007 & 3.5480 & 1.0001 & 1.0001 & 0.0005 & 0.4515 \\
$\mathrm{CAN}-22$ & 12.0105 & 7.9827 & 2.0013 & 2.0013 & 0.0079 & 0.0094 \\
$\mathrm{CAN}-23$ & 12.0011 & 7.8501 & 2.0001 & 2.0001 & 0.0008 & 0.1491 \\
$\mathrm{CAN}-24$ & 12.0008 & 7.5507 & 2.0001 & 2.0001 & 0.0006 & 0.4487 \\
\hline
\end{tabular}

For input into REACT.exe of GWB, the molarities must now be converted to molalities.

$$
[X]=(X)\left(\frac{1}{\text { density }- \text { solute mass }}\right)
$$

where

$[\mathrm{X}]=$ molality of component $\mathrm{X}$

$(\mathrm{X})=$ molarity of component $\mathrm{X}$

density $=$ solution density in $\mathrm{kg} / \mathrm{L}$

solute mass $=$ mass in $\mathrm{kg}$ of solute in $1 \mathrm{~L}$ of solution

Density measurements from Tank Farm sampling were used to develop a correlation between sodium concentration and density (see Appendix B of Jantzen and Pareizs ${ }^{\S}$ )

$$
\text { density }=1.013+5.701 \cdot 10^{-2} \cdot\left(\mathrm{Na}^{+}\right)-1.725 \cdot 10^{-3} \cdot\left(\mathrm{Na}^{+}\right)^{2}
$$

\footnotetext{
$\S$ Jantzen, C. M., and J. M. Pareizs, Thermodynamic Modeling of the SSRS Evaporators: Part IV. Incorporation of High Caustic Aluminosilicate Solubility Data (U), WSRC-TR-2002-00319, Rev. 0, Savannah River Site, Aiken, SC.
} 
WSRC-TR-2002-00331, Rev. 0

The solute mass is then calculated:

$$
\text { solute mass }=\frac{1}{1000} \sum\left(X_{i}\right) M W_{i}
$$

Table A-6 through Table A-9 show the results of the conversion of equilibrium molar concentrations to equilibrium molal concentrations.

Table A-6. Calculated Solution Density, Solute Mass, and Composition in Mol / $\mathrm{kg}$ Water for $\mathbf{N A S}_{\text {gel }}$ Solutions

\begin{tabular}{|c|c|c|c|c|c|c|c|}
\hline Solution ID & $\begin{array}{c}\text { Solution } \\
\text { Density } \\
(\mathrm{kg} / \mathrm{L})\end{array}$ & $\begin{array}{c}\text { Solute Mass } \\
(\mathrm{kg} / \mathrm{L})\end{array}$ & $\mathrm{Na}^{+}$ & $\mathrm{OH}^{-}$ & $\mathrm{NO}_{2}^{-}+\mathrm{NO}_{3}^{-}$ & $\mathrm{H}_{2} \mathrm{SiO}_{4}{ }^{2-}$ & $\mathrm{Al}(\mathrm{OH})_{4}$ \\
\hline $\mathrm{T}=30^{\circ} \mathrm{C}$ & & & & & & & \\
\hline NAS-1 & 1.117 & 0.133 & 3.121 & 2.898 & 0.000 & 0.0714 & 0.0804 \\
\hline NAS-2 & 1.219 & 0.258 & 6.350 & 6.036 & 0.000 & 0.1054 & 0.1029 \\
\hline NAS-3 & 1.246 & 0.329 & 6.634 & 4.180 & 2.180 & 0.0939 & 0.0862 \\
\hline NAS-4 & 1.246 & 0.335 & 6.646 & 4.115 & 2.195 & 0.0612 & 0.2130 \\
\hline NAS-5 & 1.249 & 0.355 & 6.754 & 3.903 & 2.236 & 0.0445 & 0.5259 \\
\hline NAS-6 & 1.476 & 0.647 & 14.618 & 9.395 & 4.829 & 0.1313 & 0.1317 \\
\hline NAS-7 & 1.476 & 0.654 & 14.699 & 9.359 & 4.865 & 0.1036 & 0.2677 \\
\hline $\begin{array}{l}\text { NAS-8 } \\
\qquad \mathrm{T}=65^{\circ} \mathrm{C}\end{array}$ & 1.478 & 0.673 & 14.981 & 9.236 & 4.970 & 0.0701 & 0.6342 \\
\hline NAS-9 & 1.118 & 0.137 & 3.146 & 2.860 & 0.000 & 0.0898 & 0.1069 \\
\hline NAS-10 & 1.227 & 0.277 & 6.534 & 5.880 & 0.000 & 0.2183 & 0.2169 \\
\hline NAS-11 & 1.249 & 0.335 & 6.697 & 4.115 & 2.190 & 0.1273 & 0.1369 \\
\hline NAS-12 & 1.247 & 0.337 & 6.671 & 4.093 & 2.198 & 0.0775 & 0.2255 \\
\hline NAS-13 & 1.250 & 0.358 & 6.780 & 3.865 & 2.243 & 0.0509 & 0.5701 \\
\hline NAS-14 & 1.487 & 0.676 & 15.105 & 9.190 & 4.929 & 0.3177 & 0.3502 \\
\hline NAS-15 & 1.484 & 0.675 & 15.059 & 9.208 & 4.940 & 0.2392 & 0.4332 \\
\hline $\begin{array}{l}\text { NAS-16 } \\
\mathrm{T}=130^{\circ} \mathrm{C}\end{array}$ & 1.485 & 0.688 & 15.238 & 9.129 & 5.019 & 0.1816 & 0.7272 \\
\hline NAS-17 & 1.120 & 0.140 & 3.175 & 2.831 & 0.000 & 0.1142 & 0.1155 \\
\hline NAS-18 & 1.233 & 0.292 & 6.688 & 5.750 & 0.000 & 0.3118 & 0.3137 \\
\hline NAS-19 & 1.252 & 0.342 & 6.768 & 4.051 & 2.199 & 0.1720 & 0.1747 \\
\hline NAS-20 & 1.249 & 0.341 & 6.708 & 4.057 & 2.203 & 0.0983 & 0.2514 \\
\hline NAS-21 & 1.251 & 0.360 & 6.799 & 3.851 & 2.245 & 0.0646 & 0.5733 \\
\hline
\end{tabular}


WSRC-TR-2002-00331, Rev. 0

Table A-7. Calculated Solution Density, Solute Mass, and Composition in Mol / $\mathrm{kg}$ Water for Zeolite-A Solutions

\begin{tabular}{|c|c|c|c|c|c|c|c|}
\hline Solution ID & $\begin{array}{c}\text { Solution } \\
\text { Density } \\
(\mathrm{kg} / \mathrm{L})\end{array}$ & $\begin{array}{c}\text { Solute } \\
\text { Mass } \\
(\mathrm{kg} / \mathrm{L})\end{array}$ & $\mathrm{Na}^{+}$ & $\mathrm{OH}^{-}$ & $\mathrm{NO}_{2}^{-}+\mathrm{NO}_{3}^{-}$ & $\mathrm{H}_{2} \mathrm{SiO}_{4}^{-}$ & $\mathrm{Al}(\mathrm{OH})_{4}^{-}$ \\
\hline \multicolumn{8}{|l|}{$\mathrm{T}=30^{\circ} \mathrm{C}$} \\
\hline ZEO-1 & 1.169 & 0.123 & 2.879 & 2.837 & 0.000 & 0.0113 & 0.0192 \\
\hline ZEO-2 & 1.294 & 0.247 & 5.761 & 5.653 & 0.000 & 0.0300 & 0.0477 \\
\hline ZEO-3 & 1.293 & 0.318 & 6.166 & 4.053 & 2.050 & 0.0155 & 0.0322 \\
\hline ZEO-4 & 1.293 & 0.326 & 6.211 & 3.977 & 2.068 & 0.0061 & 0.1536 \\
\hline ZEO-5 & 1.293 & 0.349 & 6.358 & 3.765 & 2.118 & 0.0044 & 0.4659 \\
\hline ZEO-6 & 1.449 & 0.637 & 14.815 & 9.722 & 4.922 & 0.0480 & 0.0748 \\
\hline ZEO-7 & 1.449 & 0.643 & 14.918 & 9.694 & 4.964 & 0.0274 & 0.2056 \\
\hline $\begin{array}{l}\text { ZEO-8 } \\
\qquad \mathrm{T}=65^{\circ} \mathrm{C}\end{array}$ & 1.449 & 0.666 & 15.342 & 9.604 & 5.107 & 0.0220 & 0.5876 \\
\hline ZEO-9 & 1.169 & 0.124 & 2.889 & 2.825 & 0.000 & 0.0190 & 0.0257 \\
\hline ZEO-10 & 1.294 & 0.250 & 5.787 & 5.633 & 0.000 & 0.0421 & 0.0705 \\
\hline ZEO-11 & 1.294 & 0.318 & 6.172 & 4.051 & 2.050 & 0.0206 & 0.0290 \\
\hline ZEO-12 & 1.293 & 0.329 & 6.228 & 3.955 & 2.073 & 0.0083 & 0.1831 \\
\hline ZEO-13 & 1.293 & 0.350 & 6.368 & 3.753 & 2.121 & 0.0056 & 0.4837 \\
\hline ZEO-14 & 1.450 & 0.642 & 14.947 & 9.705 & 4.954 & 0.0843 & 0.1190 \\
\hline ZEO-15 & 1.449 & 0.654 & 15.127 & 9.656 & 5.027 & 0.0456 & 0.3530 \\
\hline ZEO-16 & 1.449 & 0.668 & 15.400 & 9.594 & 5.123 & 0.0319 & 0.6195 \\
\hline \multicolumn{8}{|l|}{$\mathrm{T}=130^{\circ} \mathrm{C}$} \\
\hline ZEO-17 & 1.170 & 0.126 & 2.903 & 2.811 & 0.000 & 0.0296 & 0.0328 \\
\hline ZEO-18 & 1.295 & 0.252 & 5.810 & 5.623 & 0.000 & 0.0592 & 0.0685 \\
\hline ZEO-19 & 1.294 & 0.320 & 6.190 & 4.038 & 2.053 & 0.0314 & 0.0360 \\
\hline ZEO-20 & 1.293 & 0.328 & 6.226 & 3.962 & 2.072 & 0.0109 & 0.1707 \\
\hline ZEO-21 & 1.293 & 0.351 & 6.376 & 3.745 & 2.123 & 0.0079 & 0.4929 \\
\hline ZEO-22 & 1.450 & 0.646 & 15.045 & 9.697 & 4.973 & 0.1252 & 0.1246 \\
\hline ZEO-23 & 1.449 & 0.649 & 15.066 & 9.675 & 5.000 & 0.0675 & 0.2567 \\
\hline ZEO-24 & 1.449 & 0.670 & 15.438 & 9.590 & 5.131 & 0.0454 & 0.6260 \\
\hline
\end{tabular}


WSRC-TR-2002-00331, Rev. 0

Table A-8. Calculated Solution Density, Solute Mass, and Composition in Mol / $/ \mathrm{kg}$ Water for Nitrated Sodalite Solutions

\begin{tabular}{|c|c|c|c|c|c|c|c|}
\hline Solution ID & $\begin{array}{l}\text { Solution } \\
\text { Density } \\
(\mathrm{kg} / \mathrm{L})\end{array}$ & Solute Mass $(\mathrm{kg} / \mathrm{L})$ & $\mathrm{Na}^{+}$ & $\mathrm{OH}^{-}$ & $\mathrm{NO}_{2}^{-}+\mathrm{NO}_{3}^{-}$ & $\mathrm{H}_{2} \mathrm{SiO}_{4}{ }^{2-}$ & $\mathrm{Al}(\mathrm{OH})_{4}^{-}$ \\
\hline $\mathrm{T}=30^{\circ} \mathrm{C}$ & & & & & & & \\
\hline SOD-1 & 1.169 & 0.122 & 2.875 & 2.847 & 0.002 & 0.0074 & 0.0100 \\
\hline Sod-2 & 1.294 & 0.244 & 5.737 & 5.679 & 0.006 & 0.0169 & 0.0190 \\
\hline SOD-3 & 1.293 & 0.315 & 6.143 & 4.078 & 2.047 & 0.0059 & 0.0063 \\
\hline SOD-4 & 1.293 & 0.326 & 6.209 & 3.977 & 2.070 & 0.0025 & 0.1580 \\
\hline SOD-5 & 1.293 & 0.348 & 6.353 & 3.769 & 2.118 & 0.0009 & 0.4654 \\
\hline SOD-6 & 1.449 & 0.631 & 14.678 & 9.743 & 4.891 & 0.0097 & 0.0240 \\
\hline SOD-7 & 1.449 & 0.640 & 14.846 & 9.704 & 4.948 & 0.0040 & 0.1861 \\
\hline $\begin{array}{l}\text { SOD-8 } \\
\qquad \mathrm{T}=65^{\circ} \mathrm{C}\end{array}$ & 1.449 & 0.663 & 15.284 & 9.611 & 5.094 & 0.0027 & 0.5733 \\
\hline SOD-9 & 1.169 & 0.123 & 2.885 & 2.839 & 0.005 & 0.0137 & 0.0145 \\
\hline SOD-10 & 1.294 & 0.247 & 5.770 & 5.660 & 0.010 & 0.0309 & 0.0381 \\
\hline SOD-11 & 1.294 & 0.317 & 6.161 & 4.065 & 2.052 & 0.0128 & 0.0176 \\
\hline SOD-12 & 1.293 & 0.327 & 6.213 & 3.972 & 2.071 & 0.0028 & 0.1644 \\
\hline SOD-13 & 1.293 & 0.349 & 6.359 & 3.763 & 2.119 & 0.0017 & 0.4732 \\
\hline SOD-14 & 1.449 & 0.632 & 14.718 & 9.742 & 4.904 & 0.0222 & 0.0283 \\
\hline SOD-15 & 1.449 & 0.641 & 14.861 & 9.702 & 4.953 & 0.0066 & 0.1927 \\
\hline $\begin{array}{l}\text { SOD-16 } \\
\mathrm{T}=130^{\circ} \mathrm{C}\end{array}$ & 1.449 & 0.664 & 15.302 & 9.608 & 5.100 & 0.0041 & 0.5852 \\
\hline SOD-17 & 1.170 & 0.125 & 2.900 & 2.822 & 0.007 & 0.0216 & 0.0283 \\
\hline SOD-18 & 1.295 & 0.249 & 5.793 & 5.650 & 0.014 & 0.0415 & 0.0464 \\
\hline SOD-19 & 1.294 & 0.318 & 6.172 & 4.059 & 2.055 & 0.0179 & 0.0214 \\
\hline SOD-20 & 1.293 & 0.327 & 6.213 & 3.974 & 2.071 & 0.0038 & 0.1614 \\
\hline SOD-21 & 1.293 & 0.349 & 6.363 & 3.759 & 2.121 & 0.0026 & 0.4780 \\
\hline SOD-22 & 1.449 & 0.634 & 14.770 & 9.740 & 4.919 & 0.0366 & 0.0374 \\
\hline SOD-23 & 1.449 & 0.642 & 14.882 & 9.701 & 4.959 & 0.0116 & 0.1981 \\
\hline SOD-24 & 1.449 & 0.665 & 15.315 & 9.608 & 5.104 & 0.0079 & 0.5872 \\
\hline
\end{tabular}


WSRC-TR-2002-00331, Rev. 0

Table A-9. Calculated Solution Density, Solute Mass, and Composition in Mol / $\mathrm{kg}$ Water for Nitrated Cancrinite Solutions

\begin{tabular}{lccccccc}
\hline & $\begin{array}{c}\text { Solution } \\
\text { Density } \\
(\mathrm{kg} / \mathrm{L})\end{array}$ & $\begin{array}{c}\text { Solute } \\
\text { Mass } \\
(\mathrm{kg} / \mathrm{L})\end{array}$ & $\mathrm{Na}^{+}$ & $\mathrm{OH}^{-}$ & $\mathrm{NO}_{2}{ }^{-}+\mathrm{NO}_{3}{ }^{-}$ & $\mathrm{H}_{2} \mathrm{SiO}_{4}{ }^{2-}$ & $\mathrm{Al}(\mathrm{OH})_{4}{ }^{-}$ \\
\hline $\mathrm{T}=30^{\circ} \mathrm{C}$ & & & & & & & \\
$\mathrm{CAN}-1$ & 1.169 & 0.121 & 2.870 & 2.852 & 0.001 & 0.0044 & 0.0075 \\
$\mathrm{CAN}-2$ & 1.293 & 0.242 & 5.719 & 5.688 & 0.003 & 0.0087 & 0.0111 \\
$\mathrm{CAN}-3$ & 1.293 & 0.314 & 6.134 & 4.083 & 2.045 & 0.0019 & 0.0034 \\
$\mathrm{CAN}-4$ & 1.293 & 0.325 & 6.202 & 3.983 & 2.067 & 0.0003 & 0.1514 \\
$\mathrm{CAN}-5$ & 1.293 & 0.348 & 6.353 & 3.769 & 2.117 & 0.0002 & 0.4660 \\
$\mathrm{CAN}-6$ & 1.449 & 0.629 & 14.640 & 9.746 & 4.880 & 0.0024 & 0.0094 \\
$\mathrm{CAN}-7$ & 1.449 & 0.640 & 14.835 & 9.704 & 4.945 & 0.0005 & 0.1853 \\
$\mathrm{CAN}-8$ & 1.449 & 0.663 & 15.271 & 9.612 & 5.090 & 0.0004 & 0.5674 \\
$\mathrm{~T}=65^{\circ} \mathrm{C}$ & & & & & & & \\
$\mathrm{CAN}-9$ & 1.169 & 0.122 & 2.874 & 2.848 & 0.002 & 0.0068 & 0.0096 \\
$\mathrm{CAN}-10$ & 1.294 & 0.243 & 5.728 & 5.683 & 0.004 & 0.0133 & 0.0141 \\
$\mathrm{CAN}-11$ & 1.293 & 0.315 & 6.137 & 4.080 & 2.045 & 0.0026 & 0.0058 \\
$\mathrm{CAN}-12$ & 1.293 & 0.326 & 6.204 & 3.980 & 2.068 & 0.0005 & 0.1550 \\
$\mathrm{CAN}-13$ & 1.293 & 0.349 & 6.354 & 3.767 & 2.118 & 0.0003 & 0.4687 \\
$\mathrm{CAN}-14$ & 1.449 & 0.629 & 14.650 & 9.745 & 4.883 & 0.0039 & 0.0138 \\
$\mathrm{CAN}-15$ & 1.449 & 0.640 & 14.834 & 9.704 & 4.945 & 0.0007 & 0.1838 \\
$\mathrm{CAN}-16$ & 1.449 & 0.663 & 15.281 & 9.610 & 5.094 & 0.0005 & 0.5758 \\
$\mathrm{~T}=130^{\circ} \mathrm{C}$ & & & & & & & \\
$\mathrm{CAN}-17$ & 1.169 & 0.122 & 2.879 & 2.843 & 0.003 & 0.0098 & 0.0129 \\
$\mathrm{CAN}-18$ & 1.294 & 0.244 & 5.740 & 5.677 & 0.006 & 0.0178 & 0.0211 \\
$\mathrm{CAN}-19$ & 1.293 & 0.315 & 6.143 & 4.077 & 2.047 & 0.0052 & 0.0083 \\
$\mathrm{CAN}-20$ & 1.293 & 0.327 & 6.210 & 3.973 & 2.070 & 0.0007 & 0.1653 \\
$\mathrm{CAN}-21$ & 1.293 & 0.349 & 6.359 & 3.760 & 2.120 & 0.0005 & 0.4785 \\
$\mathrm{CAN}-22$ & 1.449 & 0.630 & 14.663 & 9.746 & 4.887 & 0.0096 & 0.0115 \\
$\mathrm{CAN}-23$ & 1.449 & 0.640 & 14.836 & 9.704 & 4.945 & 0.0010 & 0.1843 \\
$\mathrm{CAN}-24$ & 1.449 & 0.663 & 15.276 & 9.612 & 5.092 & 0.0008 & 0.5712 \\
\hline
\end{tabular}

The above compositions and temperatures were then input into REACT to calculate log K values. These calculated values are given in Table A-10. 
WSRC-TR-2002-00331, Rev. 0

Table A-10. Calculated log K Values

\begin{tabular}{rlrlrlrl}
\hline Solution ID & $\log \mathrm{K}$ & Solution ID & $\log \mathrm{K}$ & Solution ID & $\log \mathrm{K}$ & Solution ID & $\log \mathrm{K}$ \\
\hline NAS-1 & 157.7136 & ZEO-1 & 140.7047 & SOD-1 & 61.8369 & CAN-1 & 59.115 \\
NAS-2 & 158.0517 & ZEO-2 & 147.9692 & Sod-2 & 65.753 & CAN-2 & 61.9907 \\
NAS-3 & 161.6694 & ZEO-3 & 147.3376 & SOD-3 & 67.7964 & CAN-3 & 63.224 \\
NAS-4 & 164.4053 & ZEO-4 & 150.9353 & SOD-4 & 74.1933 & CAN-4 & 68.5399 \\
NAS-5 & 168.2868 & ZEO-5 & 155.9014 & SOD-5 & 74.8389 & CAN-5 & 70.9204 \\
NAS-6 & 164.4158 & ZEO-6 & 155.6909 & SOD-6 & 72.833 & CAN-6 & 66.7312 \\
NAS-7 & 167.0295 & ZEO-7 & 158.1857 & SOD-7 & 75.9904 & CAN-7 & 70.5563 \\
NAS-8 & 169.9796 & ZEO-8 & 163.0089 & SOD-8 & 78.2103 & CAN-8 & 73.2006 \\
NAS-9 & 135.4874 & ZEO-9 & 119.8969 & SOD-9 & 52.6631 & CAN-9 & 48.9316 \\
NAS-10 & 141.3506 & ZEO-10 & 126.8731 & SOD-10 & 57.115 & CAN-10 & 51.4624 \\
NAS-11 & 140.6694 & ZEO-11 & 123.0464 & SOD-11 & 59.8513 & CAN-11 & 52.7639 \\
NAS-12 & 140.7778 & ZEO-12 & 128.3081 & SOD-12 & 61.9254 & CAN-12 & 57.2625 \\
NAS-13 & 144.2983 & ZEO-13 & 132.1605 & SOD-13 & 63.8669 & CAN-13 & 59.313 \\
NAS-14 & 149.3309 & ZEO-14 & 135.6953 & SOD-14 & 62.5986 & CAN-14 & 56.1631 \\
NAS-15 & 148.9351 & ZEO-15 & 138.4095 & SOD-15 & 64.5511 & CAN-15 & 58.568 \\
NAS-16 & 150.5189 & ZEO-16 & 139.8008 & SOD-16 & 66.5107 & CAN-16 & 60.9753 \\
NAS-17 & 114.779 & ZEO-17 & 101.0238 & SOD-17 & 44.4752 & CAN-17 & 39.5604 \\
NAS-18 & 122.9535 & ZEO-18 & 105.844 & SOD-18 & 47.1319 & CAN-18 & 42.0537 \\
NAS-19 & 120.7002 & ZEO-19 & 103.3125 & SOD-19 & 49.3984 & CAN-19 & 43.659 \\
NAS-20 & 119.6384 & ZEO-20 & 106.2153 & SOD-20 & 50.8114 & CAN-20 & 46.4637 \\
NAS-21 & 122.5377 & ZEO-21 & 110.9678 & SOD-21 & 53.1471 & CAN-21 & 48.85 \\
& & ZEO-22 & 114.5211 & SOD-22 & 52.5035 & CAN-22 & 45.8914 \\
& & ZEO-23 & 115.1417 & SOD-23 & 53.9479 & CAN-23 & 47.3501 \\
& & ZEO-24 & 118.1511 & SOD-24 & 56.07 & CAN-24 & 50.011 \\
\hline
\end{tabular}

The statistical software JMP ${ }^{\circledR}$ was used to fit a model of $\log \mathrm{K}$ as a function of composition. For $\mathrm{NAS}_{\text {gel }}$ and Zeolite- $\mathrm{A},\left[\mathrm{Na}^{+}\right],\left[\mathrm{Al}(\mathrm{OH})_{4}{ }^{-}\right]$, and the inverse of the temperature in Kelvin were the components of the model. For nitrated sodalite and nitrated cancrinite, $\left[\mathrm{NO}_{3}{ }^{-}\right]$was also included.

Sodium was chosen because it is the major component of the solutions. Aluminate was chosen because, when added to a starting solution, it had a major impact on solubility. The inverse temperature was chosen because the log of an equilibrium constant is typically proportional to the inverse temperature. Nitrate and nitrite were not used for $\mathrm{NAS}_{\text {gel }}$ and Zeolite-A because they had little direct impact on solubility. Hydroxide was not chosen because it is calculated from a charge balance, and highly correlated to the sodium concentration.

The resulting models are given in Table A-11. 
Table A-11. Relationships Between $\log K$ and Solution Compositions and Temperatures

\begin{tabular}{|c|c|}
\hline $\mathrm{NAS}_{\mathrm{gel}}$ & $\log \mathrm{K}=9.125 \cdot \log \left[\mathrm{Na}^{+}\right]+7.003 \cdot \log \left[\mathrm{Al}(\mathrm{OH})_{4}{ }^{-}\right]+\frac{5.277 \cdot 10^{4}}{T}-14.54$ \\
\hline Zeolite-A & $\log \mathrm{K}=16.582 \cdot \log \left[\mathrm{Na}^{+}\right]+5.883 \cdot \log \left[\mathrm{Al}(\mathrm{OH})_{4}{ }^{-}\right]+\frac{5.285 \cdot 10^{4}}{T}-32.72$ \\
\hline Nitrated Sodalite & $\log \mathrm{K}=5.367 \cdot \log \left[\mathrm{Na}^{+}\right]+3.224 \cdot \log \left[\mathrm{Al}(\mathrm{OH})_{4}{ }^{-}\right]+1.524 \cdot \log \left[\mathrm{NO}_{3}{ }^{-}\right]+\frac{2.578 \cdot 10^{4}}{T}-14.94$ \\
\hline Nitrated Cancrinite & $\log \mathrm{K}=3.529 \cdot \log \left[\mathrm{Na}^{+}\right]+3.049 \cdot \log \left[\mathrm{Al}(\mathrm{OH})_{4}{ }^{-}\right]+1.102 \cdot \log \left[\mathrm{NO}_{3}{ }^{-}\right]+\frac{2.631 \cdot 10^{4}}{T}-19.66$ \\
\hline
\end{tabular}

Using the models in Table A-11, log $\mathrm{K}$ values were calculated at $8.5 \mathrm{~m} \mathrm{Na}^{+}, 0.2 \mathrm{~m} \mathrm{Al}(\mathrm{OH})_{4}{ }^{-}$, and the following temperatures: $0,25,60,100,150,200,250$, and $300^{\circ} \mathrm{C}$. Table A-12 lists the $\log \mathrm{K}$ values calculated using the equations in Table A-11. These values were then input into the GWB thermodynamic database.

Table A-12. $\log$ K Values for Input into GWB Thermodynamic Database

\begin{tabular}{ccccc}
\hline $\begin{array}{c}\text { Temperature } \\
\left({ }^{\circ} \mathrm{C}\right)\end{array}$ & $\begin{array}{c}\text { NAS } \\
\log \mathrm{K}\end{array}$ & $\begin{array}{c}\text { Zeolite-A } \\
\log \mathrm{K}\end{array}$ & $\begin{array}{c}\text { Nitrated Sodalite } \\
\log \mathrm{K}\end{array}$ & $\begin{array}{c}\text { Nitrated Cancrinite } \\
\log \mathrm{K}\end{array}$ \\
\hline 0 & 182.3431 & 172.1567 & 82.9577 & 78.3746 \\
25 & 166.1269 & 155.9171 & 75.0350 & 70.2907 \\
60 & 147.5148 & 137.2781 & 65.9417 & 61.0123 \\
100 & 130.5209 & 120.2596 & 57.6390 & 52.5407 \\
150 & 113.7981 & 103.5127 & 49.4687 & 44.2042 \\
200 & 100.6108 & 90.3063 & 43.0258 & 37.6301 \\
250 & 89.9449 & 79.6250 & 37.8148 & 32.3131 \\
300 & 81.1405 & 70.8079 & 33.5133 & 27.9240 \\
\hline
\end{tabular}


WSRC-TR-2002-00331, Rev. 0

\section{APPENDIX B - SAMPLE REACT AND ACT2 INPUT SCRIPTS}

Sample REACT input Script Commands Description of Command

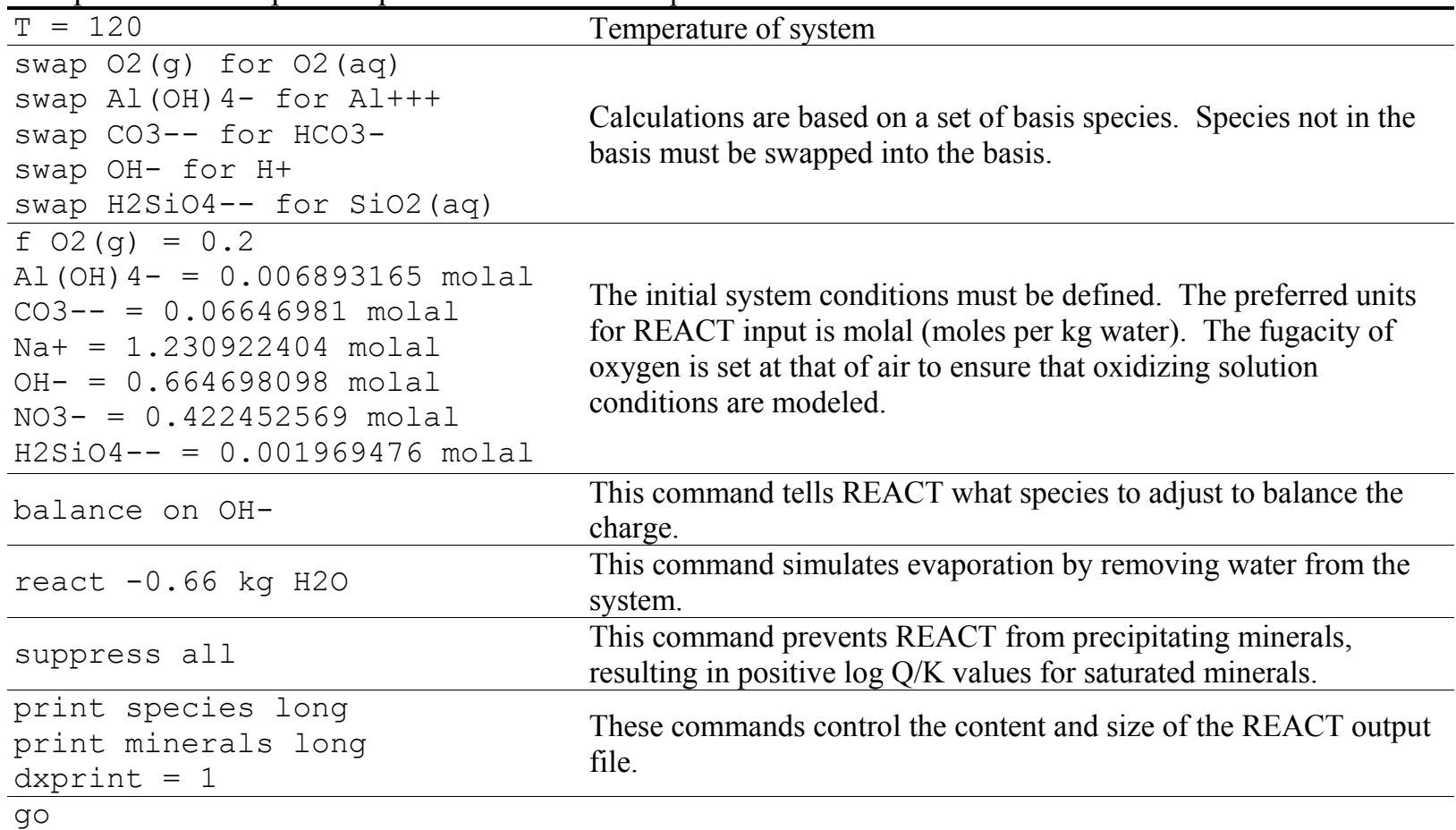

Sample ACT2 input Script Commands

$\mathrm{T}=120 \mathrm{C}$

swap Al (OH) 4-/H+ for $\mathrm{Al}+++$

swap CO3-- for $\mathrm{HCO} 3-$

swap 02 (g) for 02 (aq)

swap NAS for $\mathrm{H}+$

diagram $\mathrm{Na}+$ on $\mathrm{Al}(\mathrm{OH}) 4-/ \mathrm{H}+\mathrm{vS}$ $\mathrm{SiO} 2$ ( aq)

$\log$ a $\mathrm{Nat}=0.7666$

$\log$ a $\mathrm{NO}^{-}=0.3792$

$\log$ a $\mathrm{CO} 3--=-1.4638$

suppress Gibbsite Zeolite-A

Diaspore Beidellit-Na Nepheline

Analcime Albite Sodalite-OH

"Albite low" Paragonite "Albite

high" Boehmite Dawsonite

Corundum Mordenite-Na Jadeite

Cancrinite Sodalite-NO3

Kalsilite Muscovite

x-axis from -10 to -6 increment .5

$y$-axis from 9 to 14 increment .5

line bounds med-fine

font $=$ times
Description of Command

Temperature of system

Calculations are based on a set of basis species. Species not in the basis must be swapped into the basis.

This command specifies the species to diagram and the species on the $y$ - and $\mathrm{x}$-axes.

These commands define the system.
The suppress command prevents these minerals from being considered in the construction of the activity diagram so that the field of $\mathrm{NAS}_{\mathrm{gel}}$ can be visualized.

These commands control the display of the activity diagram. 


\section{APPENDIX C - MATTIGOD EXPERIMENTS AND REACT OUTPUT}

Temperature $=40^{\circ} \mathrm{C}$

\begin{tabular}{|c|c|c|c|c|c|c|c|c|c|c|}
\hline \multirow[b]{2}{*}{$\begin{array}{l}\text { Time } \\
\text { (hrs) }\end{array}$} & \multicolumn{5}{|c|}{ Solution Composition (molal) } & \multirow[b]{2}{*}{ Observed Phases $*$} & \multicolumn{4}{|c|}{$\log \mathrm{Q} / \mathrm{K}$} \\
\hline & $\mathrm{Si}$ & $\mathrm{Al}$ & $\mathrm{Na}$ & $\mathrm{OH}$ & NO3 & & $\mathrm{NAS}_{\mathrm{gel}}$ & Zeolite-A & $\begin{array}{l}\text { Nitrated } \\
\text { Sodalite }\end{array}$ & $\begin{array}{c}\text { Nitrated } \\
\text { Cancrinite }\end{array}$ \\
\hline Solution 1 & & & & & & & & & & \\
\hline 0 & 0.0104 & 0.1712 & 3.81 & 0.12 & 3.45 & -- & 8.9 & 19.2 & 13.7 & 18.5 \\
\hline 336 & 0.0005 & 0.1498 & NM & NM & NM & NAS/ZA & -8.5 & 1.7 & 5.0 & 9.8 \\
\hline 720 & 0.0002 & 0.1515 & NM & NM & NM & NAS/ZA & -13.2 & -3.0 & 2.6 & 7.5 \\
\hline 1080 & 0.0001 & 0.1537 & NM & NM & NM & NAS/ZA & -16.7 & -6.5 & 0.9 & 5.7 \\
\hline 1440 & 0.0001 & 0.1568 & NM & NM & NM & NAS/ZA & -16.5 & -6.3 & 1.0 & 5.8 \\
\hline Solution 2 & & & & & & & & & & \\
\hline 0 & 0.0088 & 0.4241 & 4.18 & 0.12 & 3.47 & -- & 10.5 & 20.8 & 14.6 & 19.4 \\
\hline 336 & 0.0011 & 0.4115 & NM & NM & NM & NAS/ZA & -0.9 & 9.3 & 8.9 & 13.7 \\
\hline 720 & 0.0003 & 0.4038 & NM & NM & NM & NAS/ZA & -8.0 & 2.3 & 5.3 & 10.2 \\
\hline 1080 & 0.0002 & 0.4110 & NM & NM & NM & NAS/ZA & -9.8 & 0.4 & 4.4 & 9.2 \\
\hline 1440 & 0.0002 & 0.4037 & NM & $\mathrm{NM}$ & NM & NAS/ZA & -10.1 & 0.2 & 4.3 & 9.1 \\
\hline Solution 3 & & & & & & & & & & \\
\hline 0 & 0.0096 & 0.1623 & 4.91 & 1.17 & 3.50 & -- & -3.5 & 6.7 & 7.6 & 12.4 \\
\hline 336 & 0.0010 & 0.1632 & NM & NM & NM & NAS/ZA & -15.4 & -5.1 & 1.7 & 6.5 \\
\hline 720 & 0.0005 & 0.1422 & NM & NM & NM & NAS/ZA & -19.8 & -9.6 & -0.6 & 4.3 \\
\hline 1080 & 0.0005 & 0.1639 & NM & NM & NM & NAS/ZA & -18.9 & -8.7 & -0.1 & 4.7 \\
\hline 1440 & 0.0006 & 0.1732 & NM & $\mathrm{NM}$ & NM & NAS/SOD/ZA & -17.6 & -7.4 & 0.5 & 5.4 \\
\hline Solution 4 & & & & & & & & & & \\
\hline 0 & 0.0086 & 0.4376 & 5.24 & 1.16 & 3.48 & -- & 1.0 & 11.2 & 9.9 & 14.7 \\
\hline 336 & 0.0017 & 0.4568 & NM & $\mathrm{NM}$ & NM & NAS/ZA & -7.2 & 3.1 & 5.8 & 10.7 \\
\hline 720 & 0.0007 & 0.4259 & NM & NM & NM & NAS/ZA & -12.3 & -2.1 & 3.2 & 8.1 \\
\hline 1080 & 0.0006 & 0.4176 & NM & NM & NM & NAS/ZA & -13.3 & -3.1 & 2.7 & 7.6 \\
\hline 1440 & 0.0006 & 0.4492 & NM & $\mathrm{NM}$ & NM & NAS/ZA & -12.7 & -2.5 & 3.0 & 7.9 \\
\hline Solution 5 & & & & & & & & & & \\
\hline 0 & 0.0115 & 0.1874 & 9.23 & 5.39 & 3.59 & -- & -11.1 & -0.9 & 4.1 & 8.9 \\
\hline 336 & 0.0050 & 0.1841 & NM & NM & NM & NAS/SOD/CAN & -15.6 & -5.4 & 1.8 & 6.6 \\
\hline 720 & 0.0033 & 0.1753 & NM & NM & NM & NAS/SOD/CAN & -18.0 & -7.8 & 0.6 & 5.4 \\
\hline
\end{tabular}

$\overline{N A S}=\mathrm{NAS}_{\text {gel }} ; \mathrm{ZA}=$ Zeolite-A; $\mathrm{SOD}=$ Sodalite-NO $;$ CAN = Cancrinite $; \mathrm{GIB}=$ Gibbsite; BOE $=$ Boehmite 
WSRC-TR-2002-00331, Rev. 0

Solution Composition (molal)

\begin{tabular}{|c|c|c|c|c|c|c|c|c|c|c|}
\hline \multirow[b]{2}{*}{$\begin{array}{l}\text { Time } \\
\text { (hrs) }\end{array}$} & \multicolumn{5}{|c|}{ Solution Composition (molal) } & \multirow[b]{2}{*}{ Observed Phases } & \multicolumn{4}{|c|}{$\log \mathrm{Q} / \mathrm{K}$} \\
\hline & $\mathrm{Si}$ & $\mathrm{Al}$ & $\mathrm{Na}$ & $\mathrm{OH}$ & NO3 & & $\mathrm{NAS}_{\text {gel }}$ & Zeolite-A & $\begin{array}{l}\text { Nitrated } \\
\text { Sodalite }\end{array}$ & $\begin{array}{c}\text { Nitrated } \\
\text { Cancrinite }\end{array}$ \\
\hline 1080 & 0.0025 & 0.1791 & $\mathrm{NM}$ & NM & NM & NAS/SOD/CAN & -19.4 & -9.2 & -0.1 & 4.8 \\
\hline 1440 & 0.0026 & 0.1934 & NM & NM & NM & NAS/SOD/CAN & -18.7 & -8.5 & 0.3 & 5.1 \\
\hline Solution 6 & & & & & & & & & & \\
\hline 0 & 0.0121 & 0.4987 & 9.83 & 5.52 & 3.68 & -- & -5.5 & 4.7 & 6.9 & 11.7 \\
\hline 336 & 0.0015 & 0.4695 & NM & NM & NM & $\mathrm{NAS} / \mathrm{SOD} / \mathrm{CAN}$ & -16.8 & -6.6 & 1.3 & 6.1 \\
\hline 720 & 0.0023 & 0.4712 & NM & NM & NM & NAS/SOD/CAN & -14.6 & -4.4 & 2.4 & 7.2 \\
\hline 1080 & 0.0022 & 0.4873 & NM & NM & NM & $\mathrm{NAS} / \mathrm{SOD} / \mathrm{CAN}$ & -14.6 & -4.4 & 2.4 & 7.2 \\
\hline 1440 & 0.0017 & 0.5118 & NM & NM & NM & NAS/SOD/CAN & -15.6 & -5.4 & 1.9 & 6.7 \\
\hline
\end{tabular}


WSRC-TR-2002-00331, Rev. 0

Temperature $=80^{\circ} \mathrm{C}$

Solution Composition (molal)

$\log \mathrm{Q} / \mathrm{K}$

\begin{tabular}{|c|c|c|c|c|c|c|c|c|c|c|}
\hline \multirow[b]{2}{*}{$\begin{array}{l}\text { Time } \\
\text { (hrs) }\end{array}$} & & \multirow[b]{2}{*}{ Observed Phases } & \\
\hline & $\mathrm{Si}$ & $\mathrm{Al}$ & $\mathrm{Na}$ & $\mathrm{OH}$ & NO3 & & $\mathrm{NAS}_{\mathrm{gel}}$ & Zeolite-A & $\begin{array}{l}\text { Nitrated } \\
\text { Sodalite }\end{array}$ & $\begin{array}{c}\text { Nitrated } \\
\text { Cancrinite }\end{array}$ \\
\hline \multicolumn{11}{|c|}{ Solution 1} \\
\hline 0 & 0.01149 & 0.2298 & 3.81 & 0.12 & 3.45 & & 9.3 & 19.5 & 13.5 & 18.5 \\
\hline 0.1 & 0.00067 & 0.1533 & NM & NM & NM & NAS & -10.9 & -0.7 & 3.4 & 8.5 \\
\hline 0.5 & 0.00093 & 0.1616 & NM & NM & NM & NAS & -8.7 & 1.6 & 4.6 & 9.6 \\
\hline 1 & 0.00093 & 0.1462 & NM & NM & NM & NAS & -9.6 & 0.6 & 4.1 & 9.1 \\
\hline 2 & 0.00094 & 0.1611 & NM & NM & NM & NAS & -8.6 & 1.6 & 4.6 & 9.6 \\
\hline 4 & 0.00063 & 0.1493 & NM & NM & NM & NAS & -11.5 & -1.2 & 3.1 & 8.2 \\
\hline 8 & 0.00067 & 0.1474 & NM & NM & NM & NAS/SOD & -11.3 & -1.0 & 3.2 & 8.3 \\
\hline 24 & 0.00021 & 0.1488 & NM & NM & NM & NAS/SOD & -17.3 & -7.0 & 0.3 & 5.3 \\
\hline 48 & 0.00011 & 0.1487 & NM & NM & NM & NAS/SOD & -20.6 & -10.4 & -1.4 & 3.6 \\
\hline 168 & 0.00004 & 0.1555 & NM & NM & NM & NAS/SOD & -25.5 & -15.2 & -3.9 & 1.2 \\
\hline 336 & 0.00004 & 0.1588 & NM & NM & NM & NAS/SOD & -25.3 & -15.0 & -3.7 & 1.3 \\
\hline 720 & 0.00007 & 0.1573 & NM & NM & NM & NAS/SOD & -22.4 & -12.2 & -2.3 & 2.7 \\
\hline 1440 & 0.00004 & 0.1594 & NM & NM & NM & NAS/SOD & -25.2 & -15.0 & -3.7 & 1.3 \\
\hline \multicolumn{11}{|c|}{ Solution 2} \\
\hline 0 & 0.01157 & 0.5786 & 4.18 & 0.12 & 3.47 & & 14.4 & 24.6 & 16.2 & 21.2 \\
\hline 0.1 & 0.00193 & 0.4388 & NM & NM & NM & NAS & -1.2 & 9.1 & 8.4 & 13.4 \\
\hline 0.5 & 0.00175 & 0.4419 & NM & NM & NM & NAS & -1.6 & 8.7 & 8.2 & 13.2 \\
\hline 1 & 0.00176 & 0.4452 & NM & NM & NM & NAS & -1.4 & 8.8 & 8.2 & 13.3 \\
\hline 2 & 0.00197 & 0.4599 & NM & NM & NM & NAS & -0.3 & 9.9 & 8.8 & 13.8 \\
\hline 4 & 0.00129 & 0.4099 & NM & NM & NM & NAS & -4.3 & 6.0 & 6.8 & 11.8 \\
\hline 8 & 0.00125 & 0.4069 & NM & NM & NM & NAS/SOD & -4.5 & 5.7 & 6.7 & 11.7 \\
\hline 24 & 0.00035 & 0.4004 & NM & NM & NM & NAS/SOD & -11.4 & -1.2 & 3.2 & 8.3 \\
\hline 48 & 0.00018 & 0.4176 & NM & NM & NM & NAS/SOD & -14.3 & -4.1 & 1.8 & 6.8 \\
\hline 168 & 0.00007 & 0.3212 & NM & NM & NM & NAS/GIB & -22.4 & -12.2 & -2.3 & 2.8 \\
\hline 336 & 0.00006 & 0.2711 & NM & NM & NM & GIB & -24.9 & -14.7 & -3.5 & 1.5 \\
\hline 720 & 0.00007 & 0.2681 & NM & NM & NM & GIB & -24.2 & -14.0 & -3.2 & 1.9 \\
\hline 1440 & 0.00006 & 0.2527 & NM & NM & NM & GIB & -25.5 & -15.3 & -3.8 & 1.2 \\
\hline
\end{tabular}

\footnotetext{
${ }^{*} \mathrm{NAS}=\mathrm{NAS}_{\text {gel }} ; \mathrm{ZA}=$ Zeolite-A; $\mathrm{SOD}=$ Sodalite- $\mathrm{NO}_{3} ; \mathrm{CAN}=$ Cancrinite GIB $=$ Gibbsite $; \mathrm{BOE}=$ Boehmite
} 
WSRC-TR-2002-00331, Rev. 0

Solution Composition (molal)

$\log \mathrm{Q} / \mathrm{K}$

\begin{tabular}{|c|c|c|c|c|c|c|c|c|c|c|}
\hline \multirow[b]{2}{*}{$\begin{array}{l}\text { Time } \\
\text { (hrs) }\end{array}$} & \multicolumn{5}{|c|}{ Solution Composition (molal) } & \multirow[b]{2}{*}{ Observed Phases ${ }^{*}$} & \multicolumn{4}{|c|}{$\log Q / K$} \\
\hline & $\mathrm{Si}$ & $\mathrm{Al}$ & $\mathrm{Na}$ & $\mathrm{OH}$ & NO3 & & $\mathrm{NAS}_{\mathrm{gel}}$ & Zeolite-A & $\begin{array}{l}\text { Nitrated } \\
\text { Sodalite }\end{array}$ & $\begin{array}{c}\text { Nitrated } \\
\text { Cancrinite }\end{array}$ \\
\hline Solution 3 & & & & & & & & & & \\
\hline 0 & 0.01165 & 0.2331 & 4.91 & 1.17 & 3.50 & & -4.5 & 5.8 & 6.8 & 11.8 \\
\hline 0.1 & 0.01043 & 0.1793 & NM & NM & NM & NAS & -6.8 & 3.4 & 5.6 & 10.6 \\
\hline 0.5 & 0.00852 & 0.1799 & NM & NM & NM & NAS & -7.9 & 2.4 & 5.1 & 10.1 \\
\hline 1 & 0.00828 & 0.1795 & NM & NM & NM & NAS & -8.0 & 2.2 & 5.0 & 10.0 \\
\hline 2 & 0.00813 & 0.1754 & NM & NM & NM & NAS/SOD & -8.3 & 2.0 & 4.9 & 9.9 \\
\hline 4 & 0.00527 & 0.1662 & NM & NM & NM & NAS/SOD & -10.9 & -0.7 & 3.5 & 8.6 \\
\hline 8 & 0.00187 & 0.1665 & NM & $\mathrm{NM}$ & NM & NAS/SOD & -16.3 & -6.1 & 0.8 & 5.9 \\
\hline 24 & 0.00068 & 0.1640 & NM & NM & NM & NAS/SOD/CAN & -21.7 & -11.5 & -1.9 & 3.2 \\
\hline 48 & 0.00032 & 0.1574 & NM & NM & NM & $\mathrm{NAS} / \mathrm{SOD} / \mathrm{CAN}$ & -25.9 & -15.6 & -3.9 & 1.1 \\
\hline 168 & 0.00017 & 0.1618 & NM & NM & NM & NAS/SOD/CAN & -29.0 & -18.8 & -5.5 & -0.5 \\
\hline 336 & 0.00022 & 0.1616 & NM & NM & NM & NAS/SOD/CAN & -27.7 & -17.4 & -4.8 & 0.2 \\
\hline 720 & 0.00011 & 0.1683 & NM & NM & NM & NAS/SOD/CAN & -31.0 & -20.8 & -6.5 & -1.5 \\
\hline 1440 & 0.00012 & 0.1786 & NM & NM & NM & NAS/SOD/CAN & -30.2 & -20.0 & -6.1 & -1.1 \\
\hline Solution 4 & & & & & & & & & & \\
\hline 0 & 0.01161 & 0.5806 & 5.24 & 1.16 & 3.48 & -- & 0.7 & 10.9 & 9.4 & 14.4 \\
\hline 0.1 & 0.01110 & 0.4648 & $\mathrm{NM}$ & NM & NM & NAS & -1.5 & 8.7 & 8.3 & 13.3 \\
\hline 0.5 & 0.00939 & 0.4531 & NM & NM & NM & NAS & -2.6 & 7.6 & 7.7 & 12.8 \\
\hline 1 & 0.00290 & 0.4908 & NM & NM & NM & NAS & -8.1 & 2.1 & 5.0 & 10.0 \\
\hline 2 & 0.00207 & 0.4748 & NM & NM & NM & NAS/SOD & -10.2 & 0.1 & 4.0 & 9.0 \\
\hline 4 & -- & 0.4512 & NM & NM & NM & NAS/SOD & $\mathrm{N} / \mathrm{A}$ & N/A & $\mathrm{N} / \mathrm{A}$ & N/A \\
\hline 8 & 0.00249 & 0.3993 & NM & NM & NM & NAS/SOD/CAN & -10.6 & -0.3 & 3.7 & 8.8 \\
\hline 24 & 0.00084 & 0.4206 & NM & NM & NM & $\mathrm{NAS} / \mathrm{SOD} / \mathrm{CAN}$ & -15.8 & -5.6 & 1.1 & 6.1 \\
\hline 48 & 0.00032 & 0.4324 & NM & NM & NM & NAS/SOD/CAN & -20.7 & -10.4 & -1.3 & 3.7 \\
\hline 168 & 0.00019 & 0.4305 & NM & NM & NM & NAS/SOD/CAN & -23.4 & -13.2 & -2.7 & 2.3 \\
\hline 336 & 0.00017 & 0.4303 & NM & NM & NM & NAS/SOD/CAN & -24.0 & -13.8 & -3.0 & 2.1 \\
\hline 720 & 0.00014 & 0.4165 & NM & NM & NM & NAS/SOD/CAN & -25.3 & -15.0 & -3.6 & 1.4 \\
\hline 1440 & 0.00014 & 0.4093 & $\mathrm{NM}$ & NM & NM & NAS/SOD/CAN & -25.4 & -15.2 & -3.7 & 1.4 \\
\hline
\end{tabular}


WSRC-TR-2002-00331, Rev. 0

Solution Composition (molal)

$\log \mathrm{Q} / \mathrm{K}$

\begin{tabular}{|c|c|c|c|c|c|c|c|c|c|c|}
\hline \multirow[b]{2}{*}{$\begin{array}{l}\text { Time } \\
\text { (hrs) }\end{array}$} & \multicolumn{5}{|c|}{ Solution Composition (molal) } & \multirow[b]{2}{*}{ Observed Phases ${ }^{*}$} & \multicolumn{4}{|c|}{$\log$} \\
\hline & $\mathrm{Si}$ & $\mathrm{Al}$ & $\mathrm{Na}$ & $\mathrm{OH}$ & NO3 & & $\mathrm{NAS}_{\mathrm{gel}}$ & Zeolite-A & $\begin{array}{l}\text { Nitrated } \\
\text { Sodalite }\end{array}$ & $\begin{array}{c}\text { Nitrated } \\
\text { Cancrinite }\end{array}$ \\
\hline \multicolumn{11}{|l|}{ Solution 5} \\
\hline 0 & 0.01197 & 0.2394 & 9.23 & 5.39 & 3.59 & -- & -14.0 & -3.8 & 2.2 & 7.3 \\
\hline 0.1 & 0.01360 & 0.1762 & NM & NM & NM & NAS/SOD/CAN & -15.1 & -4.9 & 1.7 & 6.7 \\
\hline 2 & 0.01371 & 0.1830 & NM & $\mathrm{NM}$ & NM & NAS/SOD/CAN & -14.9 & -4.6 & 1.8 & 6.9 \\
\hline 3 & 0.01280 & 0.1775 & NM & $\mathrm{NM}$ & NM & NAS/SOD/CAN & -15.4 & -5.1 & 1.6 & 6.6 \\
\hline 3.5 & 0.01331 & 0.1776 & NM & NM & NM & NAS/SOD/CAN & -15.2 & -4.9 & 1.7 & 6.7 \\
\hline 4 & -- & 0.1960 & NM & NM & NM & NAS/SOD/CAN & $\mathrm{N} / \mathrm{A}$ & $\mathrm{N} / \mathrm{A}$ & $\mathrm{N} / \mathrm{A}$ & N/A \\
\hline 8 & 0.00111 & 0.1848 & NM & $\mathrm{NM}$ & NM & NAS/SOD/CAN & -27.9 & -17.7 & -4.7 & 0.3 \\
\hline 24 & 0.00127 & 0.1801 & NM & NM & NM & NAS/SOD/CAN & -27.4 & -17.1 & -4.4 & 0.6 \\
\hline 48 & 0.00210 & 0.1965 & NM & $\mathrm{NM}$ & NM & NAS/SOD/CAN & -24.3 & -14.0 & -2.9 & 2.1 \\
\hline 168 & 0.00111 & 0.1939 & NM & NM & NM & NAS/SOD/CAN & -27.7 & -17.4 & -4.6 & 0.4 \\
\hline 336 & 0.00046 & 0.1845 & NM & NM & NM & NAS/SOD/CAN & -32.5 & -22.3 & -7.0 & -2.0 \\
\hline 720 & 0.00044 & 0.1914 & NM & $\mathrm{NM}$ & NM & $\mathrm{SOD} / \mathrm{CAN}$ & -32.6 & -22.3 & -7.0 & -2.0 \\
\hline 1440 & 0.00041 & 0.1973 & NM & $\mathrm{NM}$ & NM & SOD/CAN & -32.8 & -22.5 & -7.1 & -2.1 \\
\hline \multicolumn{11}{|l|}{ Solution 6} \\
\hline 0 & 0.01227 & 0.6133 & 9.83 & 5.52 & 3.68 & -- & -8.6 & 1.6 & 5.0 & 10.0 \\
\hline 0.1 & 0.01019 & 0.4568 & NM & NM & NM & NAS/SOD & -11.5 & -1.2 & 3.6 & 8.6 \\
\hline 2 & 0.01385 & 0.4730 & NM & $\mathrm{NM}$ & NM & NAS/SOD/CAN & -9.7 & 0.6 & 4.5 & 9.5 \\
\hline 3 & 0.01388 & 0.4725 & NM & $\mathrm{NM}$ & NM & NAS/SOD/CAN & -9.7 & 0.6 & 4.5 & 9.5 \\
\hline 3.5 & 0.01267 & 0.4673 & NM & NM & NM & NAS/SOD/CAN & -10.2 & 0.0 & 4.2 & 9.2 \\
\hline 4 & 0.00064 & 0.4840 & NM & $\mathrm{NM}$ & NM & NAS/SOD/CAN & -25.6 & -15.3 & -3.5 & 1.5 \\
\hline 8 & 0.00165 & 0.4864 & NM & NM & NM & NAS/SOD/CAN & -20.6 & -10.4 & -1.0 & 4.0 \\
\hline 24 & 0.00165 & 0.5017 & NM & $\mathrm{NM}$ & NM & NAS/SOD/CAN & -20.4 & -10.2 & -0.9 & 4.1 \\
\hline 48 & 0.00167 & 0.4879 & NM & $\mathrm{NM}$ & NM & NAS/SOD/CAN & -20.5 & -10.3 & -0.9 & 4.1 \\
\hline 168 & 0.00096 & -- & NM & NM & NM & NAS/SOD/CAN & $\mathrm{N} / \mathrm{A}$ & $\mathrm{N} / \mathrm{A}$ & $\mathrm{N} / \mathrm{A}$ & N/A \\
\hline 336 & 0.00061 & 0.4526 & NM & NM & NM & NAS/SOD/CAN & -26.3 & -16.0 & -3.8 & 1.2 \\
\hline 720 & 0.00035 & 0.4925 & NM & $\mathrm{NM}$ & NM & NAS/SOD/CAN & -28.6 & -18.4 & -5.0 & 0.0 \\
\hline 1440 & 0.00040 & 0.4966 & NM & $\mathrm{NM}$ & NM & NAS/SOD/CAN & -27.9 & -17.6 & -4.6 & 0.4 \\
\hline
\end{tabular}


WSRC-TR-2002-00331, Rev. 0

Temperature $=120^{\circ} \mathrm{C}$

Solution Composition (molal)

$\log \mathrm{Q} / \mathrm{K}$

\begin{tabular}{|c|c|c|c|c|c|c|c|c|c|c|}
\hline \multirow[b]{2}{*}{$\begin{array}{l}\text { Time } \\
(\mathrm{hrs})\end{array}$} & & \multirow[b]{2}{*}{ Observed Phases } & \\
\hline & $\mathrm{Si}$ & $\mathrm{Al}$ & $\mathrm{Na}$ & $\mathrm{OH}$ & $\mathrm{NO} 3$ & & $\mathrm{NAS}_{\mathrm{gel}}$ & Zeolite-A & $\begin{array}{l}\text { Nitrated } \\
\text { Sodalite }\end{array}$ & $\begin{array}{c}\text { Nitrated } \\
\text { Cancrinite }\end{array}$ \\
\hline \multicolumn{11}{|c|}{ Solution 1} \\
\hline 0 & 0.0115 & 0.2298 & 3.81 & 0.11 & 3.45 & -- & 12.2 & 22.5 & 14.6 & 19.8 \\
\hline 0.5 & 0.0068 & 0.1247 & $\mathrm{~N} / \mathrm{M}$ & $\mathrm{N} / \mathrm{M}$ & $\mathrm{N} / \mathrm{M}$ & NAS & 2.3 & 12.5 & 9.6 & 14.8 \\
\hline 1 & 0.0036 & 0.1438 & $\mathrm{~N} / \mathrm{M}$ & $\mathrm{N} / \mathrm{M}$ & $\mathrm{N} / \mathrm{M}$ & NAS & 0.1 & 10.4 & 8.6 & 13.7 \\
\hline 2 & 0.0025 & 0.14 & $\mathrm{~N} / \mathrm{M}$ & $\mathrm{N} / \mathrm{M}$ & $\mathrm{N} / \mathrm{M}$ & NAS/SOD & -2.1 & 8.2 & 7.5 & 12.6 \\
\hline 4 & 0.0011 & 0.1396 & $\mathrm{~N} / \mathrm{M}$ & $\mathrm{N} / \mathrm{M}$ & $\mathrm{N} / \mathrm{M}$ & NAS/SOD & -6.4 & 3.9 & 5.3 & 10.5 \\
\hline 8 & 0.0005 & 0.1368 & $\mathrm{~N} / \mathrm{M}$ & $\mathrm{N} / \mathrm{M}$ & $\mathrm{N} / \mathrm{M}$ & NAS/SOD & -10.7 & -0.5 & 3.1 & 8.3 \\
\hline 24 & 0.0003 & 0.1343 & $\mathrm{~N} / \mathrm{M}$ & $\mathrm{N} / \mathrm{M}$ & N/M & NAS/SOD & -13.6 & -3.3 & 1.7 & 6.9 \\
\hline \multicolumn{11}{|c|}{ Solution 2} \\
\hline 0 & 0.0116 & 0.5786 & 4.18 & 0.12 & 3.47 & -- & 17.4 & 27.6 & 17.2 & 22.4 \\
\hline 0.5 & 0.0007 & 0.3692 & $\mathrm{~N} / \mathrm{M}$ & $\mathrm{N} / \mathrm{M}$ & $\mathrm{N} / \mathrm{M}$ & NAS & -6.2 & 4.1 & 5.5 & 10.6 \\
\hline 1 & 0.0025 & 0.3422 & $\mathrm{~N} / \mathrm{M}$ & $\mathrm{N} / \mathrm{M}$ & $\mathrm{N} / \mathrm{M}$ & NAS & -0.4 & 9.9 & 8.3 & 13.5 \\
\hline 2 & 0.0013 & 0.3281 & $\mathrm{~N} / \mathrm{M}$ & $\mathrm{N} / \mathrm{M}$ & $\mathrm{N} / \mathrm{M}$ & NAS/SOD & -4.3 & 5.9 & 6.4 & 11.6 \\
\hline 4 & 0.0007 & 0.3357 & $\mathrm{~N} / \mathrm{M}$ & $\mathrm{N} / \mathrm{M}$ & $\mathrm{N} / \mathrm{M}$ & NAS/SOD & -7.3 & 3.0 & 4.9 & 10.1 \\
\hline 8 & 0.0004 & 0.3041 & $\mathrm{~N} / \mathrm{M}$ & $\mathrm{N} / \mathrm{M}$ & $\mathrm{N} / \mathrm{M}$ & NAS/SOD/GIB & -11.3 & -1.0 & 2.9 & 8.1 \\
\hline 24 & 0.0007 & 0.2875 & $\mathrm{~N} / \mathrm{M}$ & $\mathrm{N} / \mathrm{M}$ & $\mathrm{N} / \mathrm{M}$ & NAS/SOD & -9.0 & 1.3 & 4.1 & 9.2 \\
\hline \multicolumn{11}{|c|}{ Solution 3} \\
\hline 0 & 0.0117 & 0.2331 & 4.91 & 1.17 & 3.5 & -- & -2.3 & 8.0 & 7.5 & 12.6 \\
\hline 0.5 & 0.0068 & 0.1247 & $\mathrm{~N} / \mathrm{M}$ & $\mathrm{N} / \mathrm{M}$ & $\mathrm{N} / \mathrm{M}$ & NAS/SOD & -9.2 & 1.0 & 4.0 & 9.2 \\
\hline 1 & 0.0036 & 0.1438 & $\mathrm{~N} / \mathrm{M}$ & $\mathrm{N} / \mathrm{M}$ & $\mathrm{N} / \mathrm{M}$ & NAS/SOD & -11.7 & -1.4 & 2.8 & 7.9 \\
\hline 2 & 0.0025 & 0.14 & $\mathrm{~N} / \mathrm{M}$ & $\mathrm{N} / \mathrm{M}$ & $\mathrm{N} / \mathrm{M}$ & NAS/SOD & -13.8 & -3.5 & 1.7 & 6.9 \\
\hline 4 & 0.0011 & 0.1396 & $\mathrm{~N} / \mathrm{M}$ & $\mathrm{N} / \mathrm{M}$ & $\mathrm{N} / \mathrm{M}$ & NAS/SOD/CAN & -18.1 & -7.8 & -0.4 & 4.7 \\
\hline 8 & 0.0005 & 0.1368 & $\mathrm{~N} / \mathrm{M}$ & $\mathrm{N} / \mathrm{M}$ & $\mathrm{N} / \mathrm{M}$ & NAS/SOD/CAN & -22.3 & -12.1 & -2.6 & 2.6 \\
\hline 24 & 0.0003 & 0.1343 & $\mathrm{~N} / \mathrm{M}$ & $\mathrm{N} / \mathrm{M}$ & $\mathrm{N} / \mathrm{M}$ & NAS/SOD/CAN & -25.1 & -14.8 & -3.9 & 1.2 \\
\hline \multicolumn{11}{|c|}{ Solution 4} \\
\hline 0 & 0.0116 & 0.5806 & 5.24 & 1.16 & 3.48 & -- & 2.9 & 13.1 & 10.1 & 15.3 \\
\hline 0.5 & 0.0034 & 0.3488 & $\mathrm{~N} / \mathrm{M}$ & $\mathrm{N} / \mathrm{M}$ & $\mathrm{N} / \mathrm{M}$ & NAS/SOD/CAN & -7.9 & 2.4 & 4.7 & 9.9 \\
\hline 1 & 0.0013 & 0.3053 & $\mathrm{~N} / \mathrm{M}$ & $\mathrm{N} / \mathrm{M}$ & $\mathrm{N} / \mathrm{M}$ & NAS/SOD/CAN & -13.9 & -3.6 & 1.7 & 6.9 \\
\hline 2 & 0.0008 & 0.3184 & $\mathrm{~N} / \mathrm{M}$ & $\mathrm{N} / \mathrm{M}$ & $\mathrm{N} / \mathrm{M}$ & NAS/SOD/CAN & -16.1 & -5.8 & 0.6 & 5.8 \\
\hline 4 & 0.0005 & 0.333 & $\mathrm{~N} / \mathrm{M}$ & $\mathrm{N} / \mathrm{M}$ & $\mathrm{N} / \mathrm{M}$ & NAS/SOD/CAN & -18.2 & -8.0 & -0.5 & 4.7 \\
\hline 8 & 0.0003 & 0.3181 & $\mathrm{~N} / \mathrm{M}$ & $\mathrm{N} / \mathrm{M}$ & $\mathrm{N} / \mathrm{M}$ & NAS/SOD/CAN & -21.2 & -11.0 & -2.0 & 3.2 \\
\hline
\end{tabular}

${ }^{\ddagger} \mathrm{NAS}=\mathrm{NAS}_{\text {gel }} ; \mathrm{ZA}=$ Zeolite-A; $\mathrm{SOD}=$ Sodalite- $\mathrm{NO}_{3} ; \mathrm{CAN}=$ Cancrinite $; \mathrm{GIB}=$ Gibbsite $; \mathrm{BOE}=$ Boehmite 
WSRC-TR-2002-00331, Rev. 0

Solution Composition (molal)

$\log \mathrm{Q} / \mathrm{K}$

\begin{tabular}{|c|c|c|c|c|c|c|c|c|c|c|}
\hline \multirow[b]{2}{*}{$\begin{array}{l}\text { Time } \\
\text { (hrs) }\end{array}$} & \multicolumn{5}{|c|}{ Solution Composition (molal) } & \multirow[b]{2}{*}{ Observed Phases ${ }^{*}$} & \\
\hline & $\mathrm{Si}$ & $\mathrm{Al}$ & $\mathrm{Na}$ & $\mathrm{OH}$ & NO3 & & $\mathrm{NAS}_{\mathrm{gel}}$ & Zeolite-A & $\begin{array}{l}\text { Nitrated } \\
\text { Sodalite }\end{array}$ & $\begin{array}{c}\text { Nitrated } \\
\text { Cancrinite }\end{array}$ \\
\hline 24 & 0.0001 & 0.3317 & $\mathrm{~N} / \mathrm{M}$ & $\mathrm{N} / \mathrm{M}$ & $\mathrm{N} / \mathrm{M}$ & NAS/SOD/CAN & -26.7 & -16.4 & -4.7 & 0.5 \\
\hline Solution 5 & & & & & & & & & & \\
\hline 0 & 0.012 & 0.2394 & 9.23 & 5.39 & 3.59 & -- & -12.3 & -2.0 & 2.7 & 7.9 \\
\hline 0.5 & 0.0048 & 0.0886 & $\mathrm{~N} / \mathrm{M}$ & $\mathrm{N} / \mathrm{M}$ & $\mathrm{N} / \mathrm{M}$ & No obs. & -22.6 & -12.3 & -2.4 & 2.7 \\
\hline 1 & 0.0051 & 0.0986 & $\mathrm{~N} / \mathrm{M}$ & $\mathrm{N} / \mathrm{M}$ & $\mathrm{N} / \mathrm{M}$ & NAS/SOD/CAN & -21.7 & -11.4 & -2.0 & 3.2 \\
\hline 2 & 0.0043 & 0.0922 & $\mathrm{~N} / \mathrm{M}$ & $\mathrm{N} / \mathrm{M}$ & $\mathrm{N} / \mathrm{M}$ & NAS/SOD/CAN & -23.0 & -12.7 & -2.6 & 2.6 \\
\hline 4 & 0.0035 & 0.081 & $\mathrm{~N} / \mathrm{M}$ & $\mathrm{N} / \mathrm{M}$ & $\mathrm{N} / \mathrm{M}$ & NAS/SOD/CAN & -24.7 & -14.5 & -3.5 & 1.7 \\
\hline 8 & 0.0015 & 0.0913 & $\mathrm{~N} / \mathrm{M}$ & $\mathrm{N} / \mathrm{M}$ & $\mathrm{N} / \mathrm{M}$ & NAS/SOD/CAN & -28.5 & -18.2 & -5.4 & -0.2 \\
\hline 24 & 0.0013 & 0.0886 & $\mathrm{~N} / \mathrm{M}$ & $\mathrm{N} / \mathrm{M}$ & $\mathrm{N} / \mathrm{M}$ & NAS/SOD/CAN & -29.4 & -19.1 & -5.8 & -0.7 \\
\hline Solution 6 & & & & & & & & & & \\
\hline 0 & 0.01227 & 0.6132 & 9.83 & 5.52 & 3.68 & -- & -6.9 & 3.4 & 5.5 & 10.7 \\
\hline 0.5 & 0.0047 & 0.2398 & $\mathrm{~N} / \mathrm{M}$ & $\mathrm{N} / \mathrm{M}$ & $\mathrm{N} / \mathrm{M}$ & No observation & -17.6 & -7.4 & 0.1 & 5.3 \\
\hline 1 & 0.0046 & 0.2342 & $\mathrm{~N} / \mathrm{M}$ & $\mathrm{N} / \mathrm{M}$ & $\mathrm{N} / \mathrm{M}$ & NAS/SOD/CAN & -17.9 & -7.6 & 0.0 & 5.1 \\
\hline 2 & 0.004 & 0.2287 & $\mathrm{~N} / \mathrm{M}$ & $\mathrm{N} / \mathrm{M}$ & $\mathrm{N} / \mathrm{M}$ & NAS/SOD/CAN & -18.7 & -8.5 & -0.5 & 4.7 \\
\hline 4 & 0.0025 & 0.2404 & $\mathrm{~N} / \mathrm{M}$ & $\mathrm{N} / \mathrm{M}$ & $\mathrm{N} / \mathrm{M}$ & NAS/SOD/CAN & -20.9 & -10.6 & -1.5 & 3.6 \\
\hline 8 & 0.0007 & 0.2342 & $\mathrm{~N} / \mathrm{M}$ & $\mathrm{N} / \mathrm{M}$ & $\mathrm{N} / \mathrm{M}$ & NAS/SOD/CAN & -27.7 & -17.4 & -4.9 & 0.2 \\
\hline 24 & 0.0007 & 0.2622 & $\mathrm{~N} / \mathrm{M}$ & $\mathrm{N} / \mathrm{M}$ & $\mathrm{N} / \mathrm{M}$ & NAS/SOD/CAN & -27.1 & -16.8 & -4.6 & 0.6 \\
\hline
\end{tabular}


WSRC-TR-2002-00331, Rev. 0

Temperature $=175^{\circ} \mathrm{C}$

Solution Composition (molal)

$\log \mathrm{Q} / \mathrm{K}$

\begin{tabular}{|c|c|c|c|c|c|c|c|c|c|c|}
\hline \multirow[b]{2}{*}{$\begin{array}{l}\text { Time } \\
\text { (hrs) }\end{array}$} & \multicolumn{5}{|c|}{ Solution Composition (molal) } & \multirow[b]{2}{*}{ Observed Phases $\star$} & \multicolumn{4}{|c|}{$\log \mathrm{Q} / \mathrm{K}$} \\
\hline & $\mathrm{Si}$ & $\mathrm{Al}$ & $\mathrm{Na}$ & $\mathrm{OH}$ & NO3 & & $\mathrm{NAS}_{\text {gel }}$ & Zeolite-A & $\begin{array}{l}\text { Nitrated } \\
\text { Sodalite }\end{array}$ & $\begin{array}{c}\text { Nitrated } \\
\text { Cancrinite }\end{array}$ \\
\hline \multicolumn{11}{|c|}{ Solution 1} \\
\hline 0 & 0.0115 & 0.23 & 3.81 & 0.12 & 3.45 & & 14.9 & 25.2 & 15.4 & 20.8 \\
\hline 0.5 & 0.0005 & 0.1336 & $\mathrm{~N} / \mathrm{M}$ & $\mathrm{N} / \mathrm{M}$ & $\mathrm{N} / \mathrm{M}$ & NAS/SOD & -8.8 & 1.5 & 3.6 & 8.9 \\
\hline 1 & 0.0003 & 0.1302 & $\mathrm{~N} / \mathrm{M}$ & $\mathrm{N} / \mathrm{M}$ & $\mathrm{N} / \mathrm{M}$ & NAS/SOD/CAN & -11.7 & -1.4 & 2.1 & 7.4 \\
\hline 2 & 0.0002 & 0.1321 & $\mathrm{~N} / \mathrm{M}$ & $\mathrm{N} / \mathrm{M}$ & $\mathrm{N} / \mathrm{M}$ & NAS/SOD/CAN & -13.7 & -3.4 & 1.1 & 6.4 \\
\hline 4 & 0.0002 & 0.1362 & $\mathrm{~N} / \mathrm{M}$ & $\mathrm{N} / \mathrm{M}$ & $\mathrm{N} / \mathrm{M}$ & NAS/SOD/CAN & -13.4 & -3.1 & 1.2 & 6.6 \\
\hline 8 & 0.0001 & 0.1282 & $\mathrm{~N} / \mathrm{M}$ & $\mathrm{N} / \mathrm{M}$ & $\mathrm{N} / \mathrm{M}$ & NAS/SOD/CAN & -17.6 & -7.3 & -0.8 & 4.5 \\
\hline 24 & 0.0001 & 0.1211 & $\mathrm{~N} / \mathrm{M}$ & $\mathrm{N} / \mathrm{M}$ & $\mathrm{N} / \mathrm{M}$ & NAS/SOD/CAN & -18.1 & -7.8 & -1.1 & 4.2 \\
\hline \multicolumn{11}{|c|}{ Solution 2} \\
\hline 0 & 0.0116 & 0.5791 & 4.19 & 0.12 & 3.47 & & 19.7 & 30.0 & 17.9 & 23.2 \\
\hline 0.5 & 0.001 & 0.3409 & N/M & $\mathrm{N} / \mathrm{M}$ & N/M & NAS/SOD & -3.7 & 6.6 & 6.2 & 11.5 \\
\hline 1 & 0.0004 & 0.3336 & $\mathrm{~N} / \mathrm{M}$ & $\mathrm{N} / \mathrm{M}$ & $\mathrm{N} / \mathrm{M}$ & NAS/SOD & -8.7 & 1.6 & 3.7 & 9.0 \\
\hline 2 & 0.0003 & 0.3386 & N/M & N/M & $\mathrm{N} / \mathrm{M}$ & NAS/SOD & -10.0 & 0.3 & 3.0 & 8.3 \\
\hline 4 & 0.0002 & 0.343 & $\mathrm{~N} / \mathrm{M}$ & $\mathrm{N} / \mathrm{M}$ & $\mathrm{N} / \mathrm{M}$ & NAS/SOD & -12.0 & -1.7 & 2.0 & 7.4 \\
\hline 8 & 0.0001 & 0.3549 & N/M & N/M & $\mathrm{N} / \mathrm{M}$ & NAS/SOD & -15.2 & -4.9 & 0.4 & 5.8 \\
\hline 24 & 0.0001 & 0.3343 & $\mathrm{~N} / \mathrm{M}$ & $\mathrm{N} / \mathrm{M}$ & $\mathrm{N} / \mathrm{M}$ & $\begin{array}{c}\text { NAS/SOD/CAN/ } \\
\text { BOE }\end{array}$ & -15.9 & -5.6 & 0.1 & 5.4 \\
\hline \multicolumn{11}{|c|}{ Solution 3} \\
\hline 0 & 0.0117 & 0.2333 & 4.92 & 1.17 & 3.5 & & -1.6 & 8.7 & 7.3 & 12.6 \\
\hline 0.5 & 0.0008 & 0.1332 & $\mathrm{~N} / \mathrm{M}$ & $\mathrm{N} / \mathrm{M}$ & $\mathrm{N} / \mathrm{M}$ & NAS/SOD/CAN & -19.4 & -9.1 & -1.6 & 3.7 \\
\hline 1 & 0.001 & 0.1336 & $\mathrm{~N} / \mathrm{M}$ & $\mathrm{N} / \mathrm{M}$ & $\mathrm{N} / \mathrm{M}$ & $\mathrm{NAS} / \mathrm{SOD} / \mathrm{CAN}$ & -18.2 & -7.9 & -1.0 & 4.3 \\
\hline 2 & 0.0007 & 0.1317 & $\mathrm{~N} / \mathrm{M}$ & $\mathrm{N} / \mathrm{M}$ & $\mathrm{N} / \mathrm{M}$ & NAS/SOD/CAN & -20.2 & -9.9 & -2.0 & 3.3 \\
\hline 4 & 0.0005 & 0.1336 & $\mathrm{~N} / \mathrm{M}$ & $\mathrm{N} / \mathrm{M}$ & $\mathrm{N} / \mathrm{M}$ & NAS/SOD/CAN & -21.8 & -11.6 & -2.8 & 2.5 \\
\hline 8 & 0.0004 & 0.1347 & $\mathrm{~N} / \mathrm{M}$ & $\mathrm{N} / \mathrm{M}$ & $\mathrm{N} / \mathrm{M}$ & NAS/SOD/CAN & -23.0 & -12.7 & -3.4 & 1.9 \\
\hline 24 & 0.0003 & 0.1299 & $\mathrm{~N} / \mathrm{M}$ & $\mathrm{N} / \mathrm{M}$ & $\mathrm{N} / \mathrm{M}$ & NAS/SOD/CAN & -24.7 & -14.4 & -4.3 & 1.1 \\
\hline \multicolumn{11}{|c|}{ Solution 4} \\
\hline 0 & 0.0116 & 0.581 & 5.25 & 1.16 & 3.49 & & 3.7 & 14.0 & 10.0 & 15.3 \\
\hline 0.5 & 0.0008 & 0.3264 & $\mathrm{~N} / \mathrm{M}$ & $\mathrm{N} / \mathrm{M}$ & N/M & NAS/SOD/CAN & -15.3 & -5.0 & 0.5 & 5.8 \\
\hline 1 & 0.0008 & 0.3444 & $\mathrm{~N} / \mathrm{M}$ & $\mathrm{N} / \mathrm{M}$ & $\mathrm{N} / \mathrm{M}$ & NAS/SOD/CAN & -14.9 & -4.6 & 0.7 & 6.0 \\
\hline 2 & 0.0006 & 0.3367 & N/M & $\mathrm{N} / \mathrm{M}$ & $\mathrm{N} / \mathrm{M}$ & NAS/SOD/CAN & -16.5 & -6.2 & -0.1 & 5.2 \\
\hline 4 & 0.0004 & 0.3374 & N/M & $\mathrm{N} / \mathrm{M}$ & $\mathrm{N} / \mathrm{M}$ & NAS/SOD/CAN & -18.6 & -8.3 & -1.2 & 4.1 \\
\hline
\end{tabular}

${ }^{\ddagger} \mathrm{NAS}=\mathrm{NAS}_{\text {gel }} ; \mathrm{ZA}=$ Zeolite-A $; \mathrm{SOD}=$ Sodalite- $\mathrm{NO}_{3} ; \mathrm{CAN}=$ Cancrinite $; \mathrm{GIB}=$ Gibbsite $; \mathrm{BOE}=$ Boehmite 
WSRC-TR-2002-00331, Rev. 0

Solution Composition (molal)

$\log \mathrm{Q} / \mathrm{K}$

\begin{tabular}{|c|c|c|c|c|c|c|c|c|c|c|}
\hline \multirow[b]{2}{*}{$\begin{array}{l}\text { Time } \\
\text { (hrs) }\end{array}$} & \multicolumn{5}{|c|}{ Solution Composition (molal) } & \multirow[b]{2}{*}{ Observed Phases $\ddagger$} & \\
\hline & $\mathrm{Si}$ & $\mathrm{Al}$ & $\mathrm{Na}$ & $\mathrm{OH}$ & NO3 & & $\mathrm{NAS}_{\mathrm{gel}}$ & Zeolite-A & $\begin{array}{l}\text { Nitrated } \\
\text { Sodalite }\end{array}$ & $\begin{array}{c}\text { Nitrated } \\
\text { Cancrinite }\end{array}$ \\
\hline 8 & 0.0003 & 0.3555 & $\mathrm{~N} / \mathrm{M}$ & $\mathrm{N} / \mathrm{M}$ & $\mathrm{N} / \mathrm{M}$ & NAS/SOD/CAN & -19.7 & -9.4 & -1.7 & 3.6 \\
\hline 24 & 0.0002 & 0.3423 & $\mathrm{~N} / \mathrm{M}$ & $\mathrm{N} / \mathrm{M}$ & $\mathrm{N} / \mathrm{M}$ & NAS/SOD/CAN & -22.1 & -11.8 & -2.9 & 2.4 \\
\hline \multicolumn{11}{|c|}{ Solution 5} \\
\hline 0 & 0.012 & 0.2396 & 9.24 & 5.39 & 3.59 & & -12.1 & -1.8 & 2.3 & 7.6 \\
\hline 0.5 & 0.0071 & 0.146 & $\mathrm{~N} / \mathrm{M}$ & N/M & $\mathrm{N} / \mathrm{M}$ & NAS/SOD/CAN & -17.7 & -7.4 & -0.5 & 4.8 \\
\hline 1 & 0.0058 & 0.1417 & $\mathrm{~N} / \mathrm{M}$ & $\mathrm{N} / \mathrm{M}$ & $\mathrm{N} / \mathrm{M}$ & NAS/SOD/CAN & -18.9 & -8.6 & -1.1 & 4.2 \\
\hline 2 & 0.004 & 0.1409 & $\mathrm{~N} / \mathrm{M}$ & $\mathrm{N} / \mathrm{M}$ & $\mathrm{N} / \mathrm{M}$ & NAS/SOD/CAN & -20.9 & -10.6 & -2.1 & 3.2 \\
\hline 4 & 0.0028 & 0.135 & $\mathrm{~N} / \mathrm{M}$ & $\mathrm{N} / \mathrm{M}$ & $\mathrm{N} / \mathrm{M}$ & NAS/SOD/CAN & -23.0 & -12.7 & -3.2 & 2.2 \\
\hline 8 & 0.0025 & 0.1385 & $\mathrm{~N} / \mathrm{M}$ & $\mathrm{N} / \mathrm{M}$ & $\mathrm{N} / \mathrm{M}$ & $\mathrm{NAS} / \mathrm{SOD} / \mathrm{CAN}$ & -23.4 & -13.2 & -3.4 & 2.0 \\
\hline 24 & 0.002 & 0.1441 & $\mathrm{~N} / \mathrm{M}$ & $\mathrm{N} / \mathrm{M}$ & $\mathrm{N} / \mathrm{M}$ & NAS/SOD/CAN & -24.4 & -14.1 & -3.8 & 1.5 \\
\hline \multicolumn{11}{|c|}{ Solution 6} \\
\hline 0 & 0.0123 & 0.6138 & 9.84 & 5.52 & 3.68 & & -6.7 & 3.6 & 5.0 & 10.4 \\
\hline 0.5 & 0.005 & 0.3886 & N/M & $\mathrm{N} / \mathrm{M}$ & $\mathrm{N} / \mathrm{M}$ & NAS/SOD/CAN & -14.4 & -4.1 & 1.2 & 6.6 \\
\hline 1 & 0.0026 & 0.382 & $\mathrm{~N} / \mathrm{M}$ & $\mathrm{N} / \mathrm{M}$ & $\mathrm{N} / \mathrm{M}$ & NAS/SOD/CAN & -17.9 & -7.6 & -0.5 & 4.8 \\
\hline 2 & 0.0023 & 0.3783 & $\mathrm{~N} / \mathrm{M}$ & $\mathrm{N} / \mathrm{M}$ & $\mathrm{N} / \mathrm{M}$ & NAS/SOD/CAN & -18.6 & -8.3 & -0.9 & 4.4 \\
\hline 4 & 0.0016 & 0.386 & $\mathrm{~N} / \mathrm{M}$ & $\mathrm{N} / \mathrm{M}$ & $\mathrm{N} / \mathrm{M}$ & $\mathrm{NAS} / \mathrm{SOD} / \mathrm{CAN}$ & -20.4 & -10.1 & -1.8 & 3.6 \\
\hline 8 & 0.0014 & 0.3772 & $\mathrm{~N} / \mathrm{M}$ & $\mathrm{N} / \mathrm{M}$ & $\mathrm{N} / \mathrm{M}$ & NAS/SOD/CAN & -21.2 & -10.9 & -2.2 & 3.1 \\
\hline 24 & 0.0011 & 0.372 & N/M & $\mathrm{N} / \mathrm{M}$ & $\mathrm{N} / \mathrm{M}$ & NAS/SOD/CAN & -22.5 & -12.2 & -2.9 & 2.5 \\
\hline
\end{tabular}


WSRC-TR-2002-00331, Rev. 0

APPENDIX D - ACTIVITY DIAGRAMS OF MATTIGOD SOLUTIONS 
WSRC-TR-2002-00331, Rev. 0
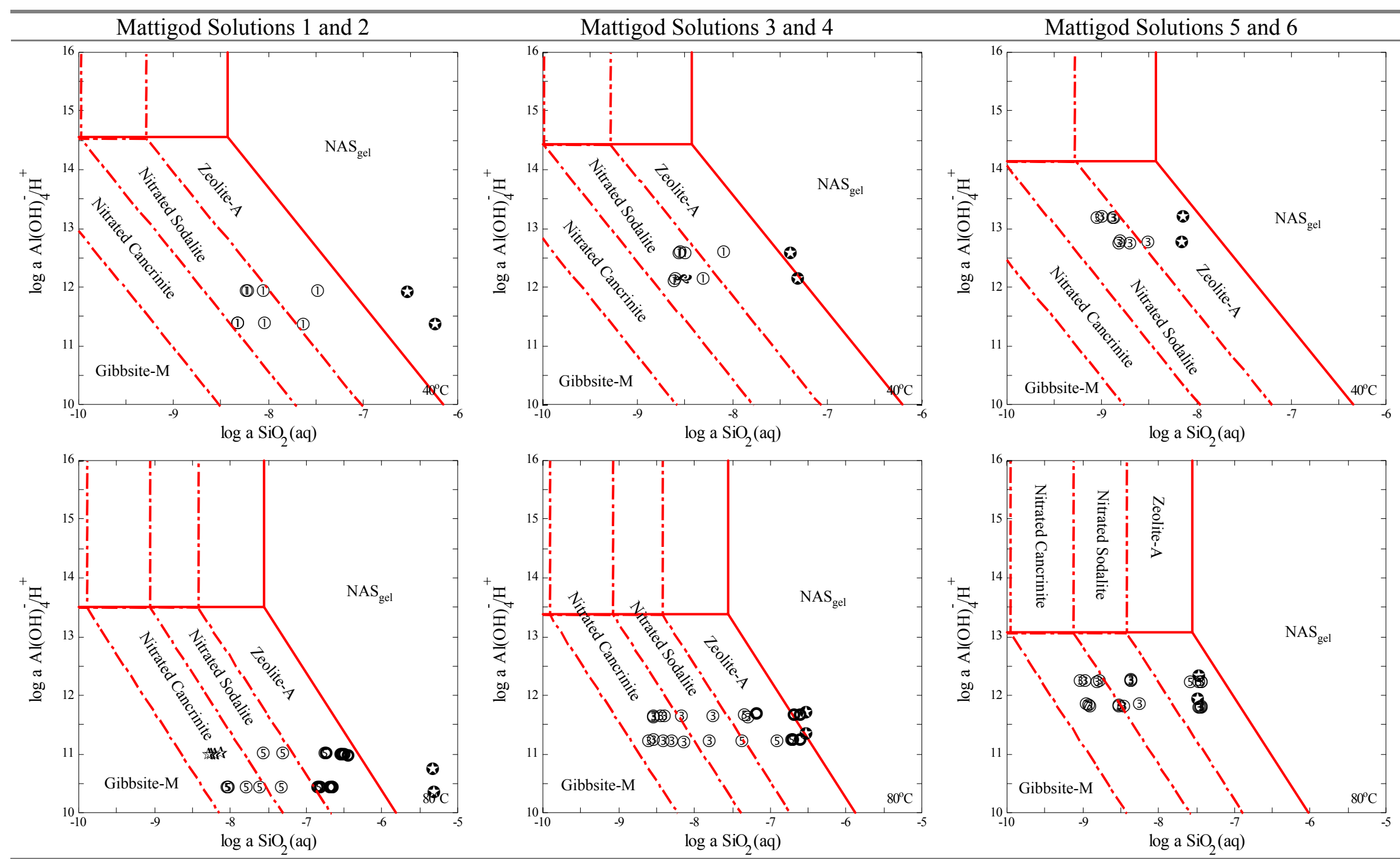
WSRC-TR-2002-00331, Rev. 0
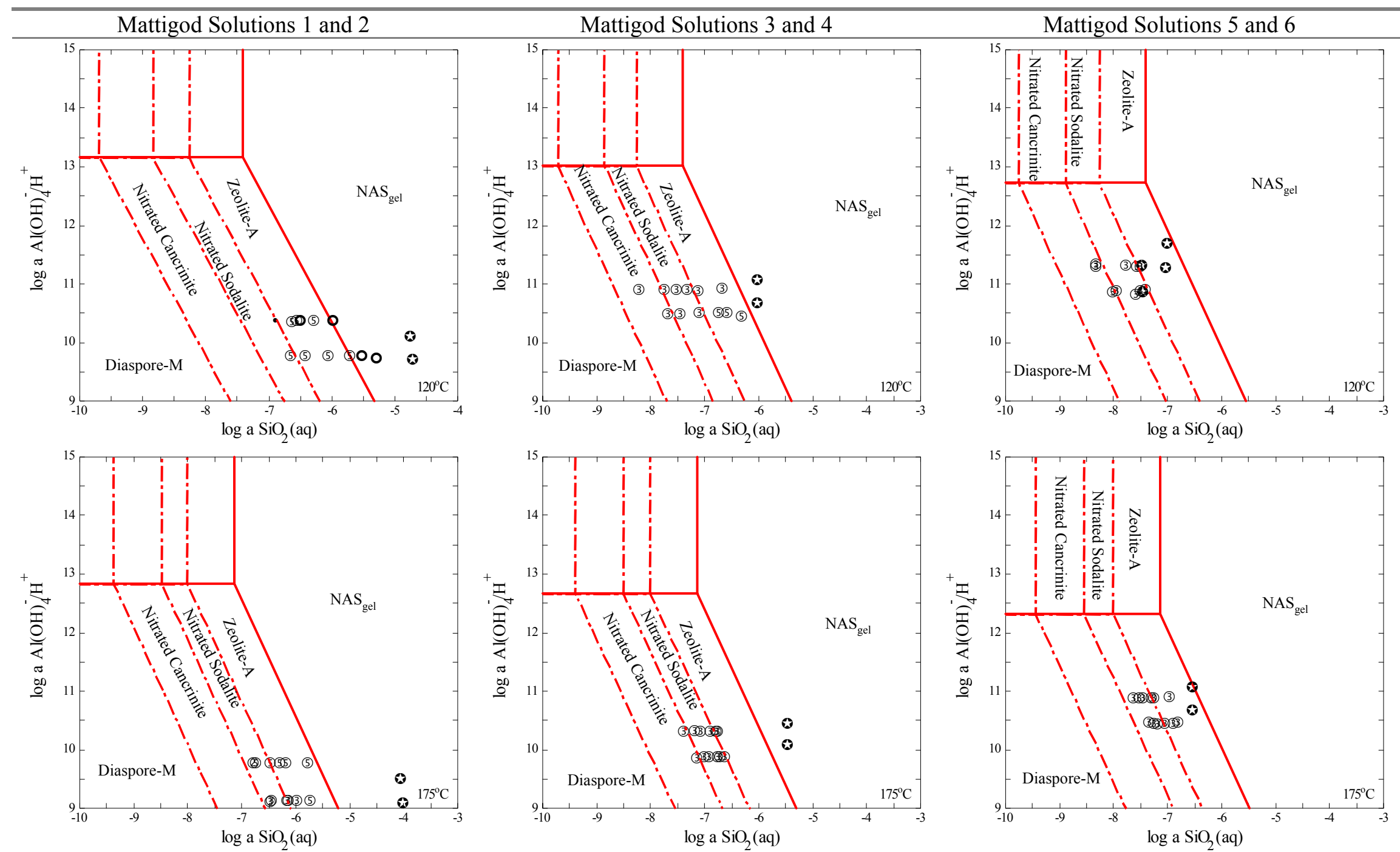

$*=\mathrm{NAS}_{\mathrm{gel}} ; \bullet=\mathrm{NAS}_{\mathrm{gel}}+$ Sodalite + Zeolite-A; $\diamond=\mathrm{NAS}_{\mathrm{gel}}+$ Sodalite; $\Delta=\mathrm{NAS}_{\mathrm{gel}}+$ Sodalite + Cancrinite; $\square=\mathrm{NAS}_{\mathrm{gel}}+\mathrm{Zeolite}-\mathrm{A} ;+=\mathrm{Al}(\mathrm{OH})_{3}$, gibbsite; $\mathrm{O}=\mathrm{NAS}_{\text {gel }}+$ boehmite + gibbsite 